Supporting Information

\title{
Asymmetric chemoenzymatic one-pot synthesis of $\alpha$-hydroxy half-esters
}

\author{
Aleksandra Murre, Kristin Erkman, Ivar Järving, and Tõnis Kanger* \\ Department of Chemistry and Biotechnology, Tallinn University of Technology, \\ Akadeemia tee 15, 12618 Tallinn, Estonia \\ Corresponding Author: E-mail: tonis.kanger@taltech.ee
}

\section{Table of Contents}

(1) Enzyme and buffer screening for hydrolysis

(2) Implementation of cyclopropenimine catalyzed [2,3]-Wittig rearrangement/PLE-mediated desymmetrization in one-pot reaction

(3) Solvent rescreening in $\mathrm{Ca}^{2+}$-catalytic [2,3]-Wittig rearrangement reaction

(4) Enantiomeric excess of the intermediates 2a-2l

(5) ${ }^{1} \mathrm{H}$ and ${ }^{13} \mathrm{C}$ NMR spectra

(6) Chiral HPLC chromatograms for compounds $\mathbf{3}$ and compound $\mathbf{4 a}$ 


\section{(1) Enzyme and buffer screening for hydrolysis}

Table S1. Enzyme screening ${ }^{a}$

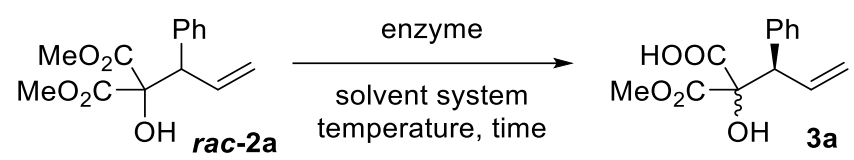

\begin{tabular}{|c|c|c|c|c|c|}
\hline Entry & Enzyme $^{b}$ & Solvent system & Time, $\mathbf{h}$ & $T$ & Conversion, $\%^{c}$ \\
\hline 1 & CALB & Phosphate buffer (pH 7.5) & 72 & rt to $60^{\circ} \mathrm{C}$ & $\mathrm{nr}$ \\
\hline 2 & CALB & Phosphate buffer (pH 7.5)/20\% DMSO & 72 & rt to $60{ }^{\circ} \mathrm{C}$ & $\mathrm{nr}$ \\
\hline 3 & CALB & $\mathrm{H}_{2} \mathrm{O}(20 \mathrm{eq}) / \mathrm{ACN}$ & 72 & rt to $60{ }^{\circ} \mathrm{C}$ & $\mathrm{nr}$ \\
\hline 4 & CRL & Phosphate buffer (pH 7.5) & 72 & rt to $40{ }^{\circ} \mathrm{C}$ & $\mathrm{nr}$ \\
\hline 5 & RML & Phosphate buffer ( $\mathrm{pH} 7.5)$ & 72 & rt to $40{ }^{\circ} \mathrm{C}$ & $\mathrm{nr}$ \\
\hline 6 & PLL & Phosphate buffer (pH 7.5) & 72 & $\mathrm{rt}$ & $\mathrm{nr}$ \\
\hline 7 & PLL & Phosphate buffer (pH 7.5)/20\% DMSO & 72 & $\mathrm{rt}$ & $\mathrm{nr}$ \\
\hline 8 & PLL & Tris buffer $(\mathrm{pH} 8.5) / 20 \%$ DMSO & 72 & $\mathrm{rt}$ & $\mathrm{nr}$ \\
\hline 9 & chymotrypsin & Phosphate buffer (pH 7.5) & 72 & $\mathrm{rt}$ & $\mathrm{nr}$ \\
\hline 10 & chymotrypsin & Tris buffer $(\mathrm{pH} 8.5) / 20 \%$ DMSO & 168 & $\mathrm{rt}$ & 14 \\
\hline $11^{d}$ & PLE & Phosphate buffer (pH 7.5) & 24 & $\mathrm{rt}$ & 34 \\
\hline
\end{tabular}

${ }^{a}$ Reaction conditions: starting material (SM) $(0.1 \mathrm{mmol})$, lyophilized enzyme (1 mmol (SM) - $\left.50 \mathrm{mg}\right)$ or immobilized enzyme (1 $\mathrm{mg}(\mathrm{SM})-1 \mathrm{mg})$, solvent $(0.2 \mathrm{M}) .{ }^{b} \mathrm{PLE}$ - esterase from porcine liver, PLL - lipase from porcine liver, CRL - lipase from Candida rugosa, RML - lipase from Rhizomucor miehei, CALB - lipase B from Candida antarctica (immobilized). ${ }^{c}$ Conversion was determined by ${ }^{1} \mathrm{H}$ NMR of the crude product. ${ }^{d}$ Product was formed with $d r 7.6: 1$ (determined by ${ }^{1} \mathrm{H}$ NMR of the crude product) and ee 15\%/ 99\% (major/minor diastereoisomers, respectively, determined by chiral HPLC).

Table S2. Buffer screening ${ }^{\mathrm{a}}$

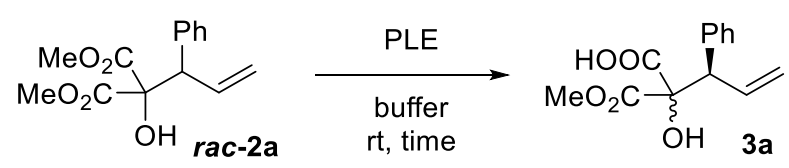

\begin{tabular}{llllll}
\hline Entry & Buffer & Time, $\mathbf{h}$ & Conversion, $\boldsymbol{\%}^{\boldsymbol{b}}$ & $\boldsymbol{d r}^{\mathbf{c}}$ & $\begin{array}{l}\boldsymbol{e e}, \boldsymbol{\%}^{\boldsymbol{d}} \\
\mathbf{m a j} / \mathbf{m i n}\end{array}$ \\
\hline $\mathbf{1}$ & Distilled water & 72 & $\mathrm{nr}$ & - & - \\
$\mathbf{2}$ & Phosphate buffer $(\mathrm{pH} \mathrm{7.5)}$ & 24 & 34 & $7.6: 1$ & $15 / 99$ \\
$\mathbf{3}$ & Phosphate buffer $(\mathrm{pH} \mathrm{8.0)}$ & 24 & 74 & $7.5: 1$ & $15 / 99$ \\
$\mathbf{4}$ & Phosphate buffer $(\mathrm{pH} \mathrm{8.5)}$ & 24 & 53 & $6.4: 1$ & $17 / 99$ \\
$\mathbf{5}$ & Tris buffer $(\mathrm{pH} \mathrm{7.4)}$ & 24 & 10 & $\mathrm{nd}$ & $\mathrm{nd}$ \\
$\mathbf{6}$ & Tris buffer $(\mathrm{pH} \mathrm{8.4)}$ & 24 & 91 & $8: 1$ & $14 / 99$ \\
$\mathbf{7}$ & Carbonate buffer $(\mathrm{pH} \mathrm{8.4)}$ & 24 & 95 & $5: 1$ & $14 / 99$ \\
$\mathbf{8}$ & Borate buffer $(\mathrm{pH} \mathrm{8.4)}$ & 24 & 23 & $6.5: 1$ & $13 / 99$ \\
$\mathbf{9}$ & Borate buffer $(\mathrm{pH} \mathrm{10.0)}$ & 24 & 25 & $4.2: 1$ & $14 / 99$ \\
\hline
\end{tabular}

${ }^{a}$ Reaction conditions: $0.1 \mathrm{mmol}$ scale, $85 \mathrm{U}$ of PLE, solvent $(0.2 \mathrm{M}) .{ }^{b}$ Conversion was determined by ${ }^{1} \mathrm{H}$ NMR of the crude product. ${ }^{c}$ Diastereoisomeric ratio was determined by ${ }^{1} \mathrm{H}$ NMR analysis of the crude mixture. ${ }^{d}$ Enantiomeric excess is determined by chiral HPLC; maj - major diastereoisomer, min - minor diastereoisomer. 


\section{(2) Implementation of cyclopropenimine catalyzed [2,3]-Wittig rearrangement/PLE-mediated desymmetrization in one-pot reaction}

First, we studied whether there was an inhibition of PLE caused by the cyclopropenimine catalyst (Table S3). No significant decrease in the rate nor selectivity of the reaction were observed in Tris buffer ( $\mathrm{pH} 8.5$, $0.2 \mathrm{M}$ ) and $\mathrm{CHCl}_{3}$ mixture in the presence of the catalytic amount of catalyst I (Table S3, entry 1) compared to the result obtained in the hydrolysis without adding catalyst I. However, only $6 \%$ of the conversion was determined for the hydrolysis carried out in the phosphate buffer $(\mathrm{pH} \mathrm{8.0,0.2} \mathrm{M)} \mathrm{with} \mathrm{DMSO} \mathrm{as} \mathrm{a} \mathrm{co-}$ solvent (Table S3, entry 2).

Table S3. Cyclopropenimine catalyst compatibility with PLE

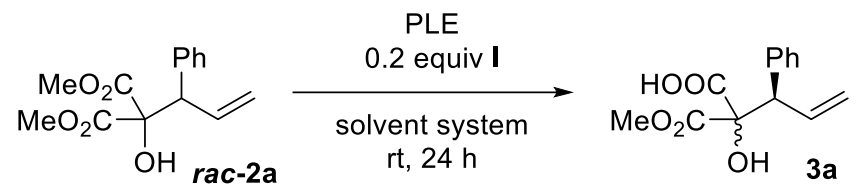

\begin{tabular}{llllll}
\hline Entry & Solvent system & Time, $\mathbf{h}$ & Conversion, $\boldsymbol{\%}^{\boldsymbol{b}}$ & $\boldsymbol{d r}^{\boldsymbol{c}}$ & $\begin{array}{l}\boldsymbol{e e}_{\mathbf{,}} \boldsymbol{\%}^{\boldsymbol{d}} \\
\mathbf{m a j} / \mathbf{m i n}\end{array}$ \\
\hline $\mathbf{1}$ & Tris buffer $(\mathrm{pH} 8.5) / 20 \% \mathrm{CHCl}_{3}$ & 72 & 58 & $7: 1$ & $48 / 85$ \\
$\mathbf{2}$ & Phosphate buffer $(\mathrm{pH} 8.0) / 20 \%$ DMSO & 24 & 6 & $1: 1$ & nd \\
\hline
\end{tabular}

${ }^{a}$ Reaction conditions: $0.1 \mathrm{mmol}$ scale, $20 \mathrm{~mol} \%$ of catalyst I, $85 \mathrm{U}$ of crude PLE, solvent system $(0.2 \mathrm{M}) .{ }^{b}$ Conversion was determined by ${ }^{1} \mathrm{H}$ NMR of the crude mixture. ${ }^{c}$ Diastereoisomeric ratio was determined by ${ }^{1} \mathrm{H}$ NMR analysis of the crude mixture. ${ }^{d}$ Enantiomeric excess was determined by chiral HPLC; maj - major diastereoisomer, min - minor diastereoisomer.

After that, we proceeded with the combination of cyclopropenimine catalyzed [2,3]-Wittig rearrangement and PLE-mediated hydrolysis in a one-pot reaction. To evaluate the results of the one-pot reaction, the hydrolysis with isolated [2,3]-Wittig rearrangement reaction product $\mathbf{2 a}$ (ee $49 \%$ ) was conducted (Table S4, reference). One-pot reactions revealed a suppression of the biotransformation with drastic decrease in both diastereoselectivity and enantioselectivity of the minor diastereoisomer.

Table S4. Combination of cyclopropenimine catalyzed [2,3]- Wittig rearrangement reaction with PLE-mediated hydrolysis in one-pot reaction

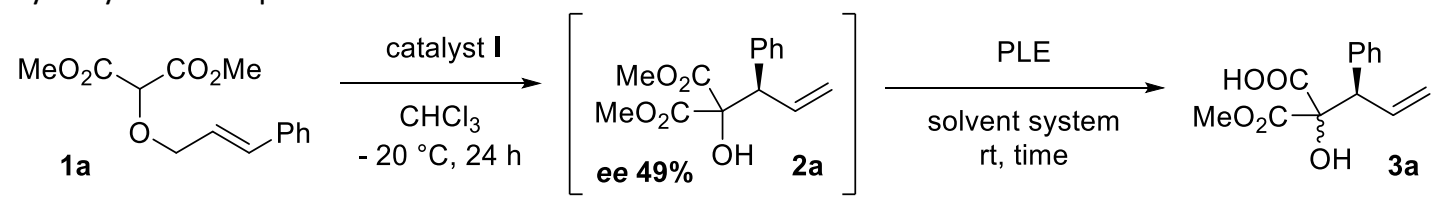

\begin{tabular}{|c|c|c|c|c|c|c|c|c|}
\hline \multirow[b]{2}{*}{ Entry } & \multirow[b]{2}{*}{ Solvent system } & \multirow{2}{*}{$\begin{array}{l}\text { Time, } \\
\text { h }\end{array}$} & \multicolumn{3}{|c|}{ One-pot ${ }^{a}: 1 \mathrm{a}->[2 \mathrm{a}]$-> $3 \mathrm{a}$} & \multicolumn{3}{|c|}{ Reference $^{b}$ : isolated $\mathbf{2 a}$-> 3a } \\
\hline & & & $\begin{array}{l}\text { Conv., } \\
\%^{c}\end{array}$ & $d r^{d}$ & $\begin{array}{l}e e, \%^{e} \\
\mathrm{maj} / \mathrm{min}\end{array}$ & $\begin{array}{l}\text { Conv., } \\
\%^{c}\end{array}$ & $d r^{d}$ & $\begin{array}{l}e e, \%^{e} \\
\mathrm{maj} / \mathrm{min}\end{array}$ \\
\hline 1 & $\begin{array}{l}\text { Tris buffer (pH 8.5) } \\
20 \% \mathrm{CHCl}_{3}\end{array}$ & 72 & 36 & $7: 1$ & $81 / 24$ & 50 & $13: 1$ & $73 / 76$ \\
\hline 2 & Phosphate buffer ( $\mathrm{pH} 8.0$ ) & 48 & 68 & $7: 1$ & $70 / 55$ & $75^{f}$ & $15: 1$ & $68 / 99$ \\
\hline 3 & $\begin{array}{l}\text { Phosphate buffer ( } \mathrm{pH} 8.0) \\
20 \% \text { DMSO }\end{array}$ & 48 & 10 & $1: 1$ & nd & 64 & $14: 1$ & 79/99 \\
\hline
\end{tabular}

${ }^{a}$ Reaction conditions: $0.1 \mathrm{mmol}$ scale, 20 mol\% of catalyst $\mathrm{I}, \mathrm{CHCl}_{3}(0.2 \mathrm{M})$ were stirred at $-20{ }^{\circ} \mathrm{C}$, followed by evaporation of solvent and addition of $85 \mathrm{U}$ of crude PLE, solvent system $(0.2 \mathrm{M}) .{ }^{b}$ Reaction conditions: $0.1 \mathrm{mmol}$ scale, $85 \mathrm{U}$ crude PLE, solvent system (0.2 M). ${ }^{c}$ Conversion was determined by ${ }^{1} \mathrm{H}$ NMR of the crude mixture. ${ }^{d}$ Diastereoisomeric ratio was determined by ${ }^{1} \mathrm{H}$ NMR analysis of the crude mixture. ${ }^{e}$ Enantiomeric excess was determined by chiral HPLC; maj - major diastereoisomer, min minor diastereoisomer. ${ }^{f}$ Reaction conversion did not change after $24 \mathrm{~h}$. 


\section{(3) Solvent rescreening in $\mathrm{Ca}^{2+}$-catalytic [2,3]-Wittig rearrangement reaction}

Table S5. Solvent screening in $\mathrm{Ca}^{2+}$-catalytic [2,3]-Wittig rearrangement reaction for $\mathbf{1} \mathbf{a}^{\mathrm{a}}$

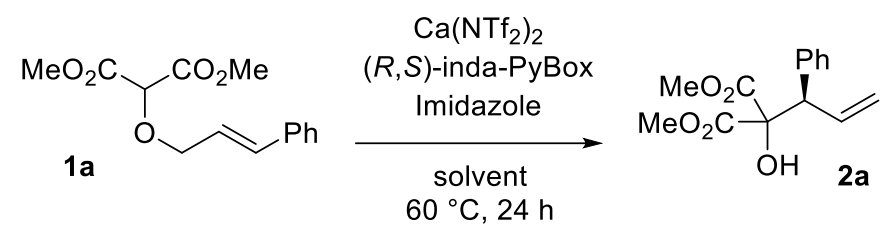

\begin{tabular}{llll}
\hline Entry & Solvent & Conversion, $\boldsymbol{\%}^{\boldsymbol{b}}$ & $\boldsymbol{e e}, \boldsymbol{\%}^{\boldsymbol{c}}$ \\
\hline $\mathbf{1}$ & THF & 40 & 78 \\
$\mathbf{2}$ & 2-MTHF & 10 & nd \\
$\mathbf{3}$ & dioxane & 14 & nd \\
$\mathbf{4}$ & DMSO & 13 & nd \\
$\mathbf{5}$ & MeOH & 100 & 24 \\
\hline
\end{tabular}

${ }^{a}$ Reaction conditions: $0.1 \mathrm{mmol}$ scale, $5 \mathrm{~mol} \%$ of $\mathrm{Ca}\left(\mathrm{NTf}_{2}\right)_{2}, 5 \mathrm{~mol} \%$ of $(R, S)$-indaPyBox, $5 \mathrm{~mol} \%$ of imidazole, solvent $(0.1 \mathrm{M}) .{ }^{b}$ Conversion was determined by ${ }^{1} \mathrm{H}$ NMR of the crude mixture. ${ }^{c}$ Enantiomeric excess was determined by chiral HPLC of the sample obtained by preparative TLC.

Table S6. Solvent screening in $\mathrm{Ca}^{2+}$-catalytic [2,3]-Wittig rearrangement reaction for $\mathbf{1} \mathbf{j}$ and $\mathbf{1} \mathbf{k}^{\mathrm{a}}$

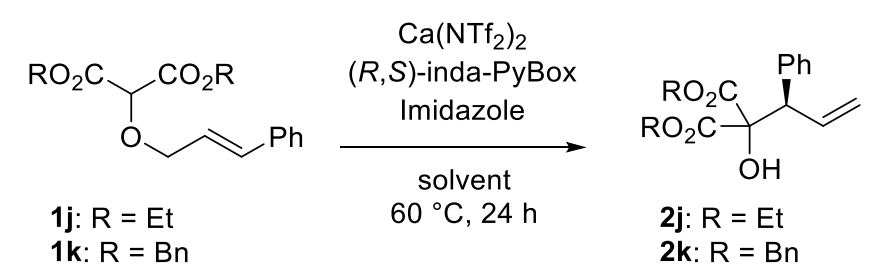

\begin{tabular}{llllll}
\hline Entry & $\mathbf{R}$ & Solvent & Conversion, $\mathbf{\%}^{\boldsymbol{b}}$ & $\begin{array}{l}\text { Transesterification } \\
\text { products, } \mathbf{\%}^{\boldsymbol{b}}\end{array}$ & $\boldsymbol{e e}_{\mathbf{,}} \mathbf{\%}^{\boldsymbol{c}}$ \\
\hline $\mathbf{1}$ & & $\mathrm{MeOH}$ & 100 & 50 & $\mathrm{nd}$ \\
$\mathbf{2}$ & $\mathrm{Et}$ & $\mathrm{EtOH}$ & 100 & 0 & 57 \\
$\mathbf{3}$ & & $i-\mathrm{PrOH}$ & 85 & 5 & 68 \\
\hline & & & & $\mathrm{nd}$ \\
\hline $\mathbf{4}$ & & $\mathrm{MeOH}$ & 100 & 100 & $\mathrm{nd}$ \\
$\mathbf{5}$ & $\mathrm{Bn}$ & $\mathrm{EtOH}$ & 100 & 76 & 76 \\
$\mathbf{6}$ & & $i-\mathrm{PrOH}$ & 100 & 0 & \\
\hline
\end{tabular}

a Reaction conditions: $0.1 \mathrm{mmol}$ scale, 5 mol\% of $\mathrm{Ca}\left(\mathrm{NTf}_{2}\right)_{2}, 5 \mathrm{~mol} \%$ of $(R, S)$-indaPyBox, $5 \mathrm{~mol} \%$ of imidazole, solvent $(0.1 \mathrm{M}) . b$ Conversion and the amount of transesterification products were determined by ${ }^{1} \mathrm{H}$ NMR of the crude mixture. ${ }^{c}$ Enantiomeric excess was determined by chiral HPLC of the sample obtained by preparative TLC. 
(4) Enantiomeric excess of the intermediates 2a-2l

Table S7. Enantiomeric excess of the intermediates $\mathbf{2 a - 2}$

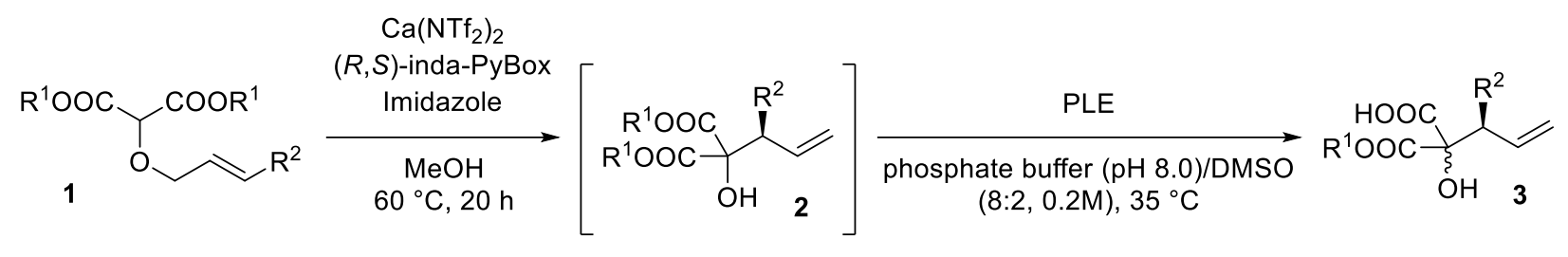

\begin{tabular}{llllllllllllll}
\hline Intermediate & $\mathbf{2} \mathbf{a}^{\mathbf{b}}$ & $\mathbf{2 \mathbf { a } ^ { c }}$ & $\mathbf{2 b}$ & $\mathbf{2 c}$ & $\mathbf{2 d}$ & $\mathbf{2 e}$ & $\mathbf{2 f}$ & $\mathbf{2 g}$ & $\mathbf{2 h}$ & $\mathbf{2 i}$ & $\mathbf{2 j}$ & $\mathbf{2 k}$ & $\mathbf{2 l}$ \\
\hline$e e, \mathbf{\%}^{a}$ & 24 & -20 & 14 & 22 & 23 & 22 & 14 & 20 & 27 & 24 & $\mathrm{nd}^{d}$ & 55 & 78 \\
\hline
\end{tabular}

${ }^{a}$ Enantiomeric excess was determined by chiral HPLC of the sample obtained by preparative TLC. ${ }^{b}(R, S)$-indaPyBox was used. ${ }^{c}$ $(S, R)$-indaPyBox was used. ${ }^{d}$ Due to low UV absorbance of the intermediate $\mathbf{2} \mathbf{i}$ enantiomeric excess could not be determined without isolation of the intermediate. 
(5) NMR spectra for compounds ethyl (E)-3-(1H-indol-1-yl)acrylate, $(E)-3-(1 H$-indol-1-yl)prop-2-en-1-ol, 1h, 1j, 1k, 1-(tert-butyl) 3-methyl 2-diazomalonate, $1 \mathrm{~m}, 1 \mathrm{n}, 3$ and $4 a$

Figure S1. ${ }^{1} \mathrm{H}$ NMR (400 MHz, $\left.\mathrm{CDCl}_{3}\right)$ of ethyl (E)-3-(1H-indol-1-yl)acrylate

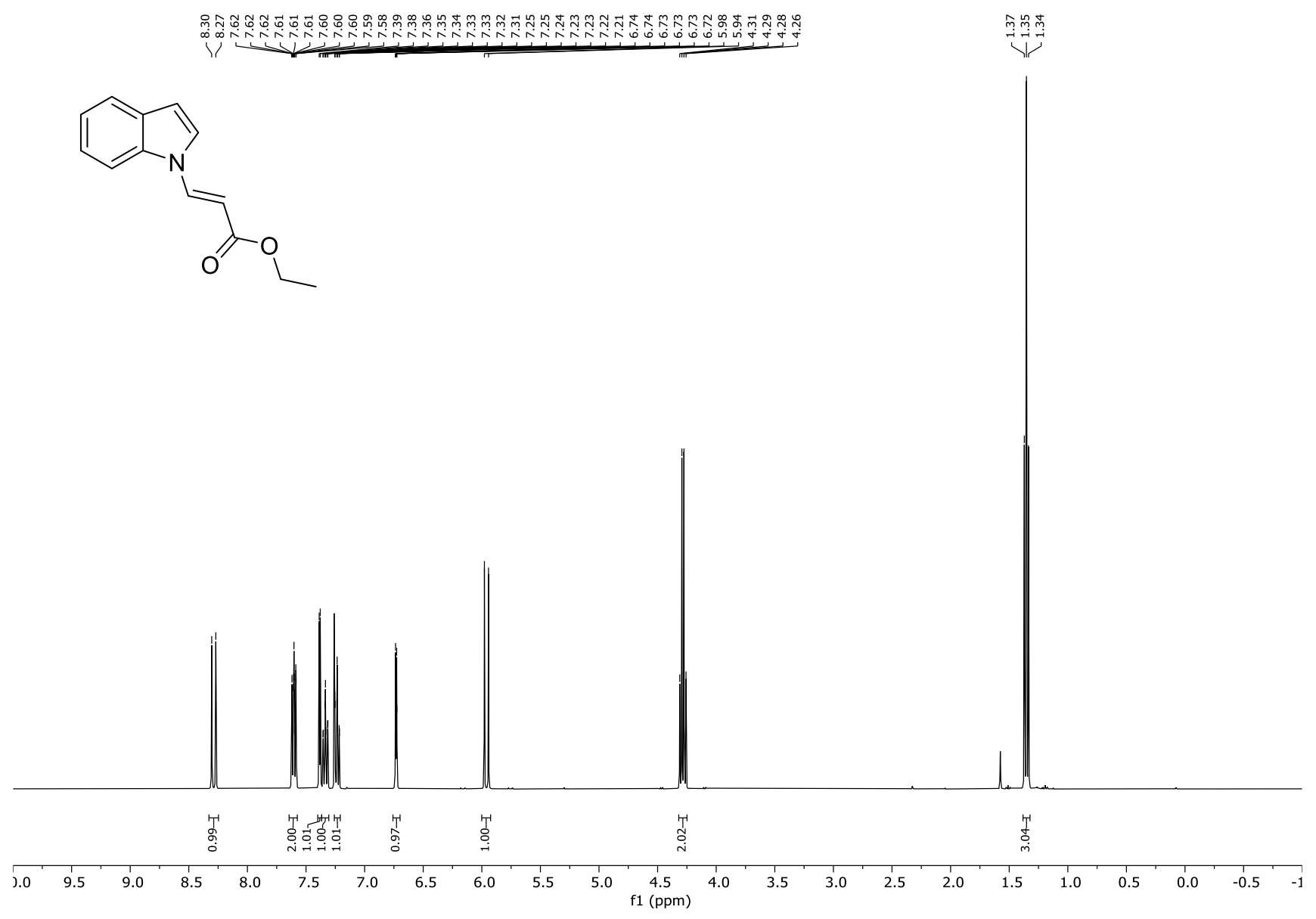


Figure S2. ${ }^{1} \mathrm{H} \mathrm{NMR}\left(400 \mathrm{MHz}, \mathrm{CDCl}_{3}\right)$ and ${ }^{13} \mathrm{C} \mathrm{NMR}\left(101 \mathrm{MHz}, \mathrm{CDCl}_{3}\right)$ of $(E)$-3-(1H-indol-1-yl)prop-2-en-1-ol
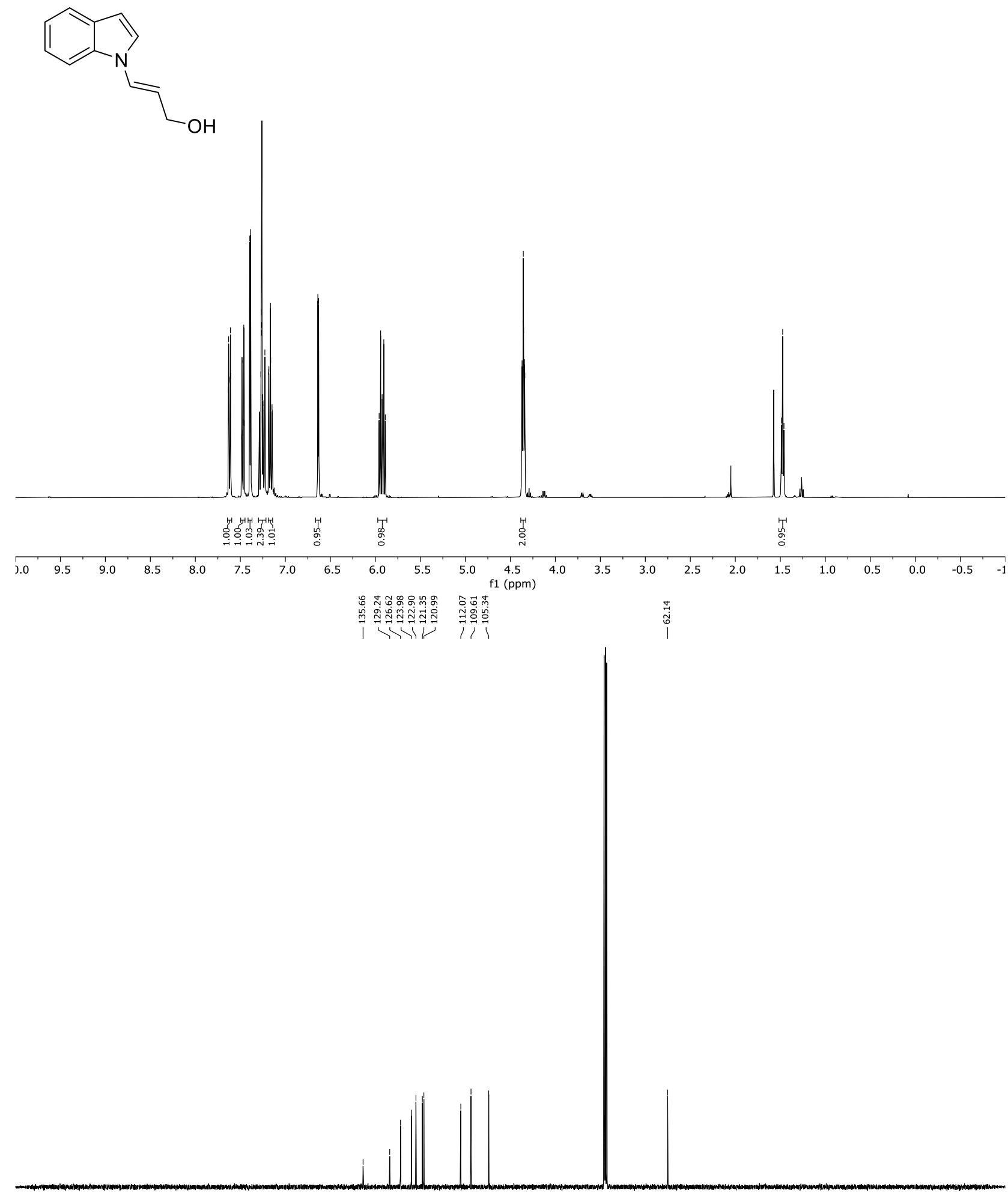
$110 \begin{array}{cc}100 \\ \mathrm{f} 1(\mathrm{ppm})\end{array}$ 
Figure S3. ${ }^{1} \mathrm{H} \mathrm{NMR}\left(400 \mathrm{MHz}, \mathrm{CDCl}_{3}\right)$ and $\left.{ }^{13} \mathrm{C} \mathrm{NMR} \mathrm{(101} \mathrm{MHz,} \mathrm{CDCl}_{3}\right)$ of $\mathbf{1 h}$

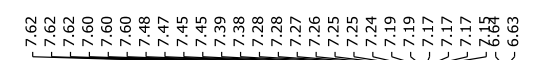

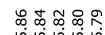

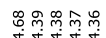

$\sqrt{1.2820}$<smiles>COC(=O)C(OC/C=C/n1ccc2ccccc21)C(C)=O</smiles>
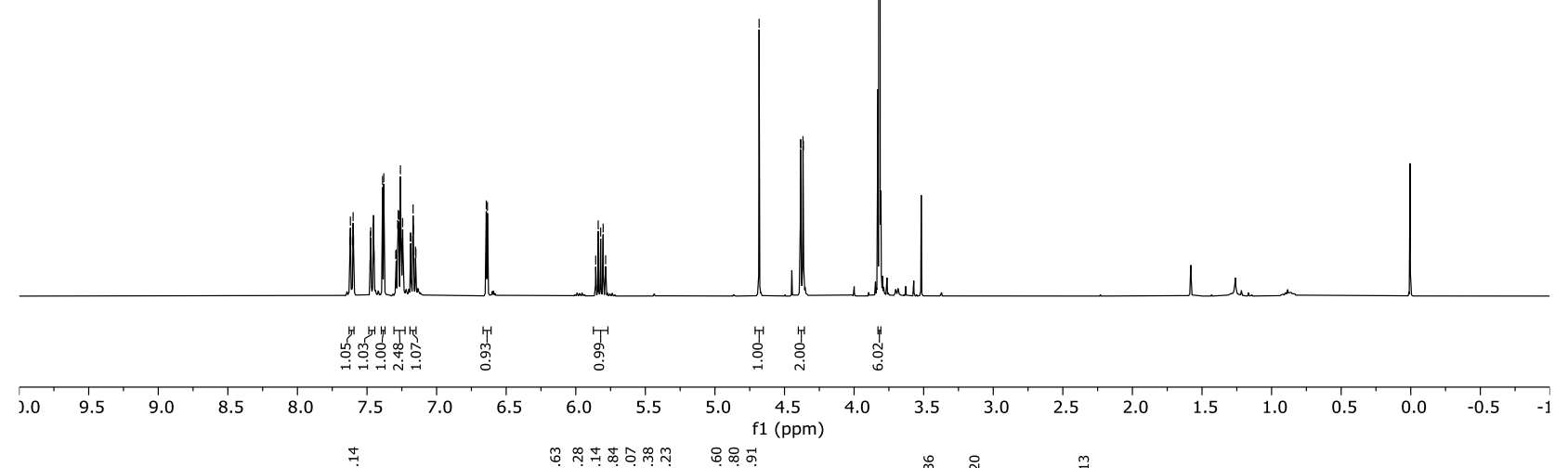

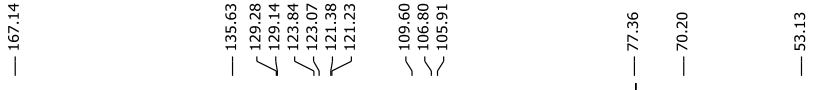

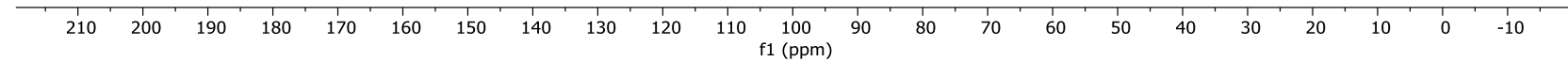


Figure S4. ${ }^{1} \mathrm{H} \mathrm{NMR}\left(400 \mathrm{MHz}, \mathrm{CDCl}_{3}\right)$ and ${ }^{13} \mathrm{C} \mathrm{NMR}\left(101 \mathrm{MHz}, \mathrm{CDCl}_{3}\right)$ of $\mathbf{1 j}$

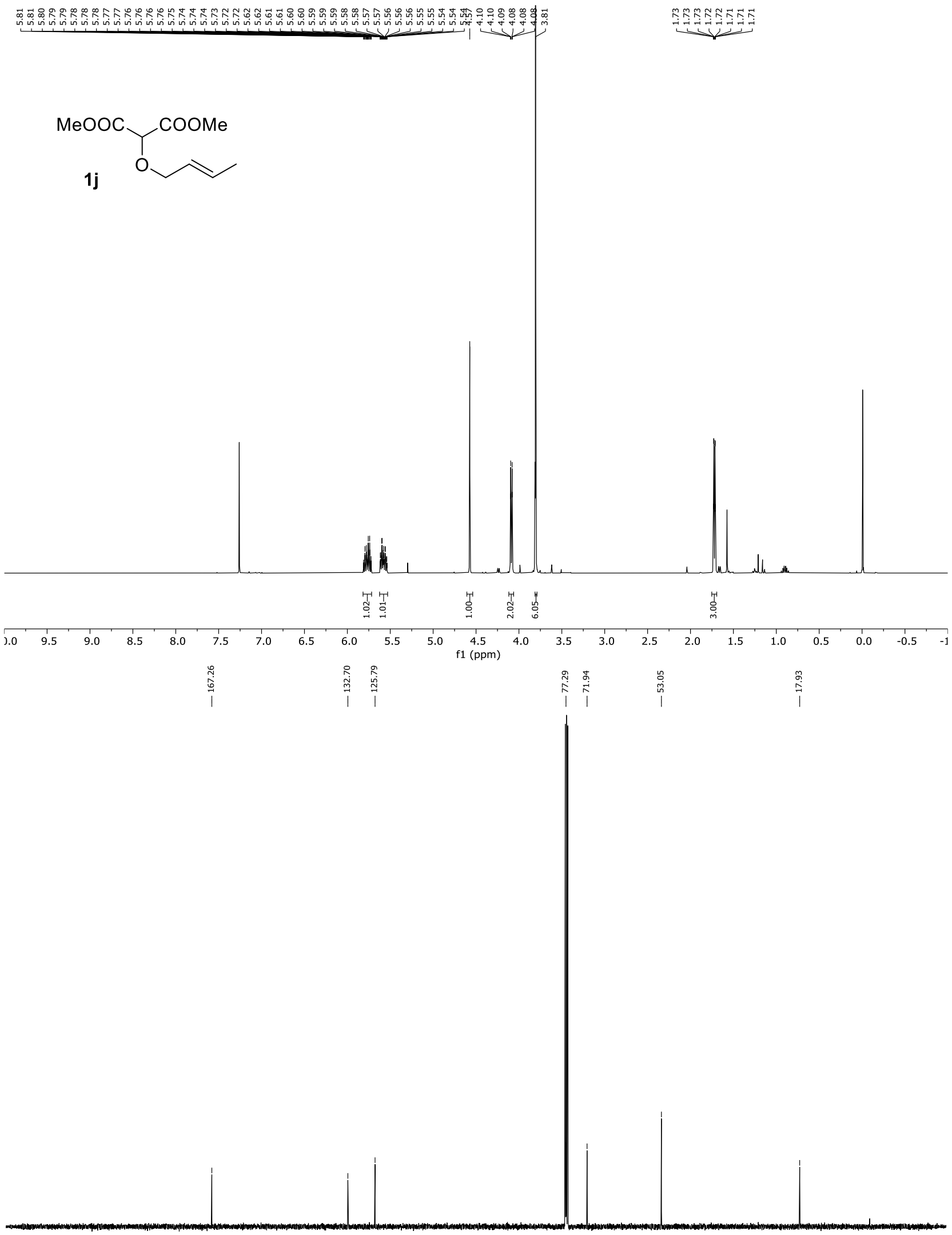

13.

$\begin{array}{lllllllllllllllllllllll}170 & 180 & 170 & 160 & 150 & 140 & 130 & 120 & 110 & \underset{f 1}{100}(\mathrm{ppm}) & 90 & 80 & 70 & 60 & 50 & 40 & 30 & 20 & 10 & 0 & -10 & \end{array}$ 
Figure S5. ${ }^{1} \mathrm{H} \mathrm{NMR}\left(400 \mathrm{MHz}, \mathrm{CDCl}_{3}\right)$ of $\mathbf{1 k}$

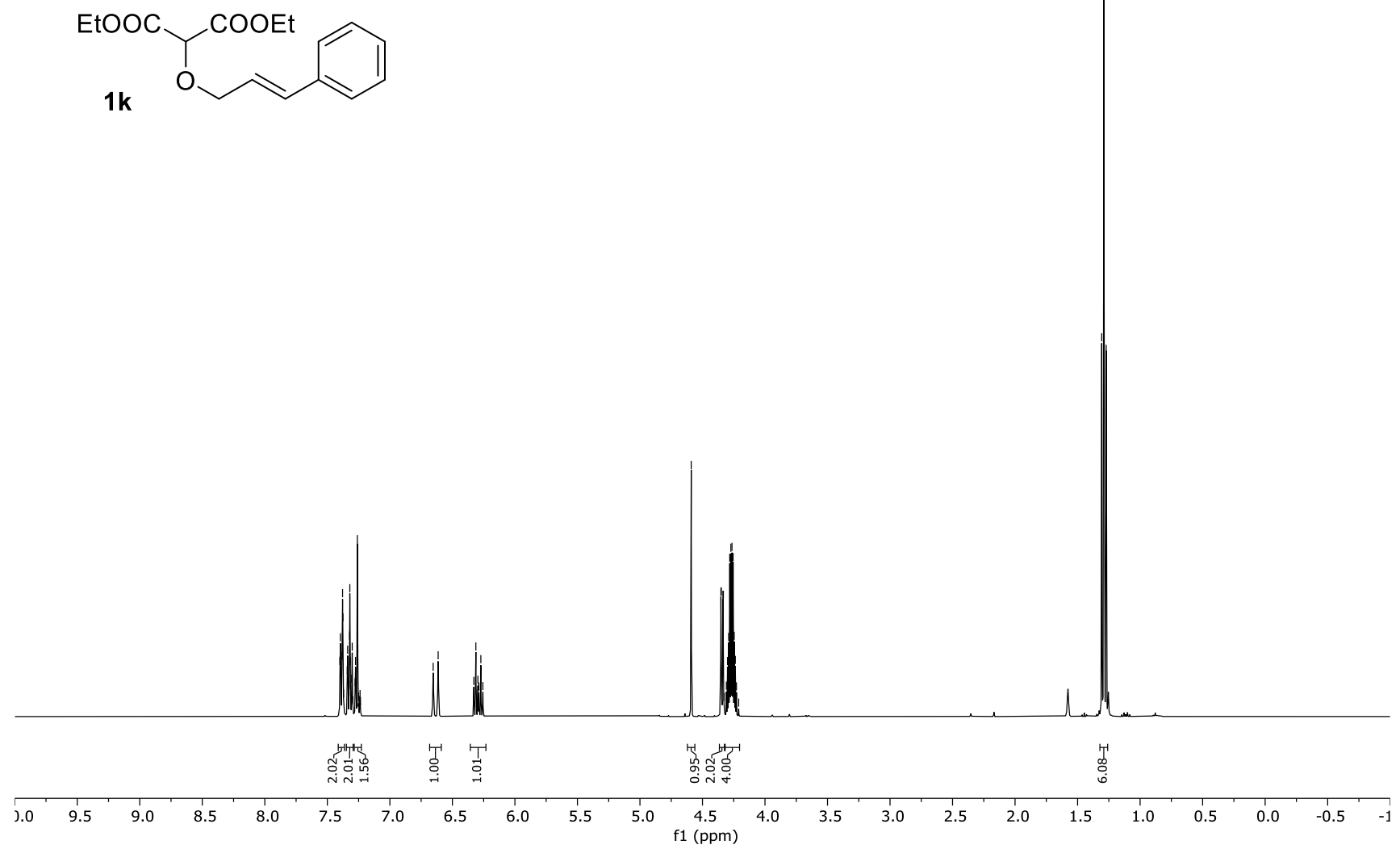


Figure S6. ${ }^{1} \mathrm{H} \mathrm{NMR}\left(400 \mathrm{MHz}, \mathrm{CDCl}_{3}\right.$ ) of 1-(tert-butyl) 3-methyl 2-diazomalonate

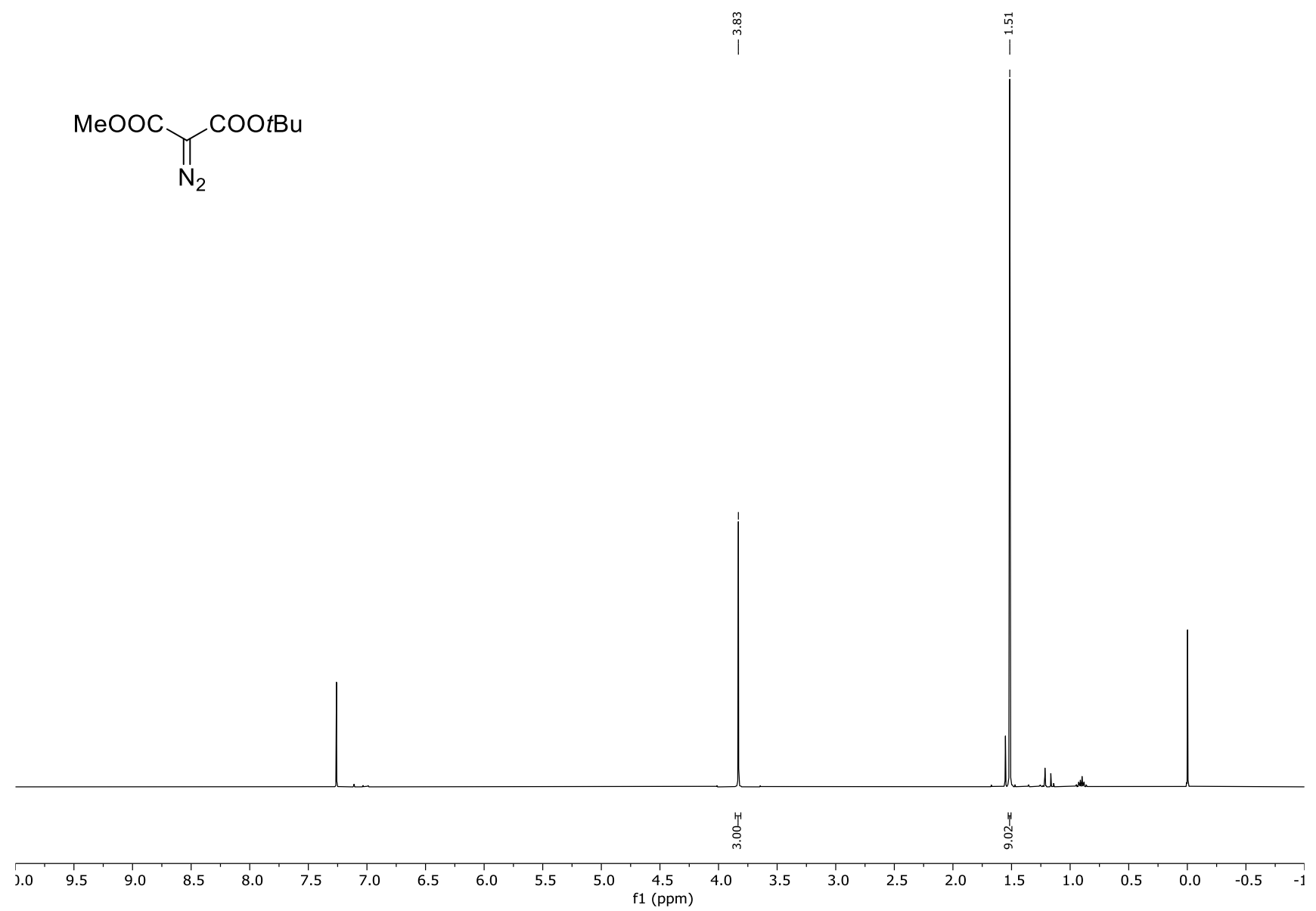


Figure S7. ${ }^{1} \mathrm{H} \mathrm{NMR}\left(400 \mathrm{MHz}, \mathrm{CDCl}_{3}\right)$ and ${ }^{13} \mathrm{C} \mathrm{NMR}\left(101 \mathrm{MHz}, \mathrm{CDCl}_{3}\right)$ of $1 \mathrm{~m}$

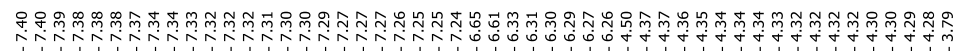<smiles>CCOC(=O)C(OC/C=C/c1ccccc1)C(OC)OC</smiles>

$1 \mathrm{~m}$
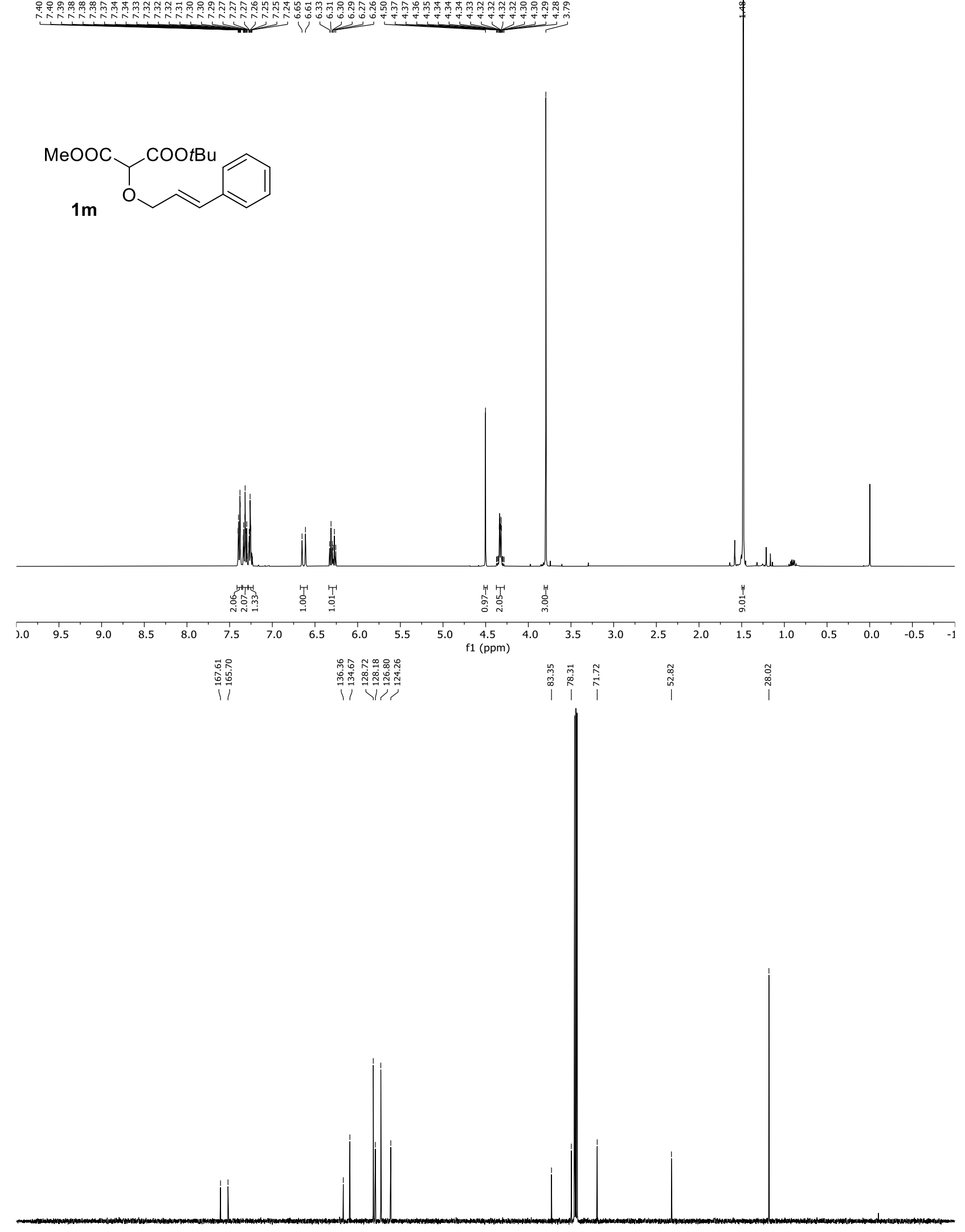

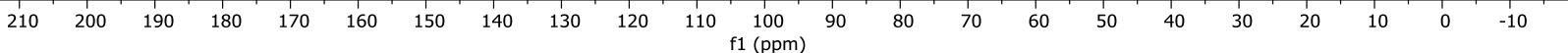


Figure S8. ${ }^{1} \mathrm{H} \mathrm{NMR}\left(400 \mathrm{MHz}, \mathrm{CDCl}_{3}\right)$ of $\mathbf{1 n}$

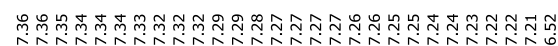

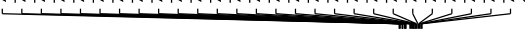

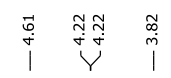

ข้ำ

MeOOC COOMe

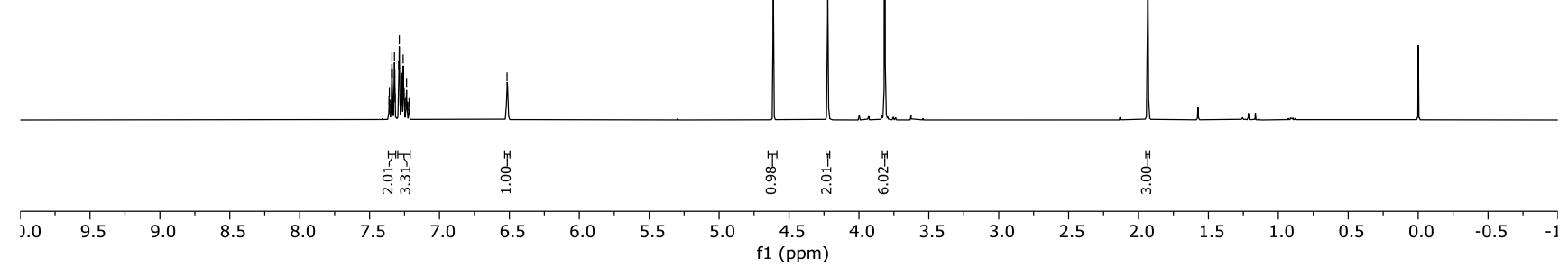


Figure S9. ${ }^{1} \mathrm{H} \mathrm{NMR}\left(400 \mathrm{MHz}, \mathrm{CDCl}_{3}\right)$ and ${ }^{13} \mathrm{C} \mathrm{NMR}\left(101 \mathrm{MHz}, \mathrm{CDCl}_{3}\right)$ of $3 \mathrm{a}$

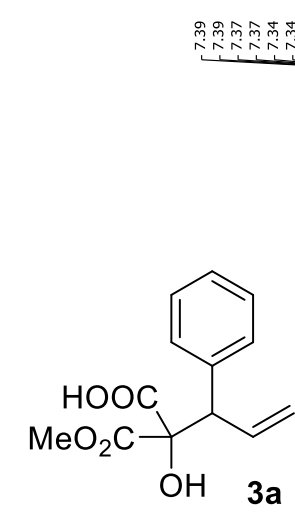

dr 2.9:1

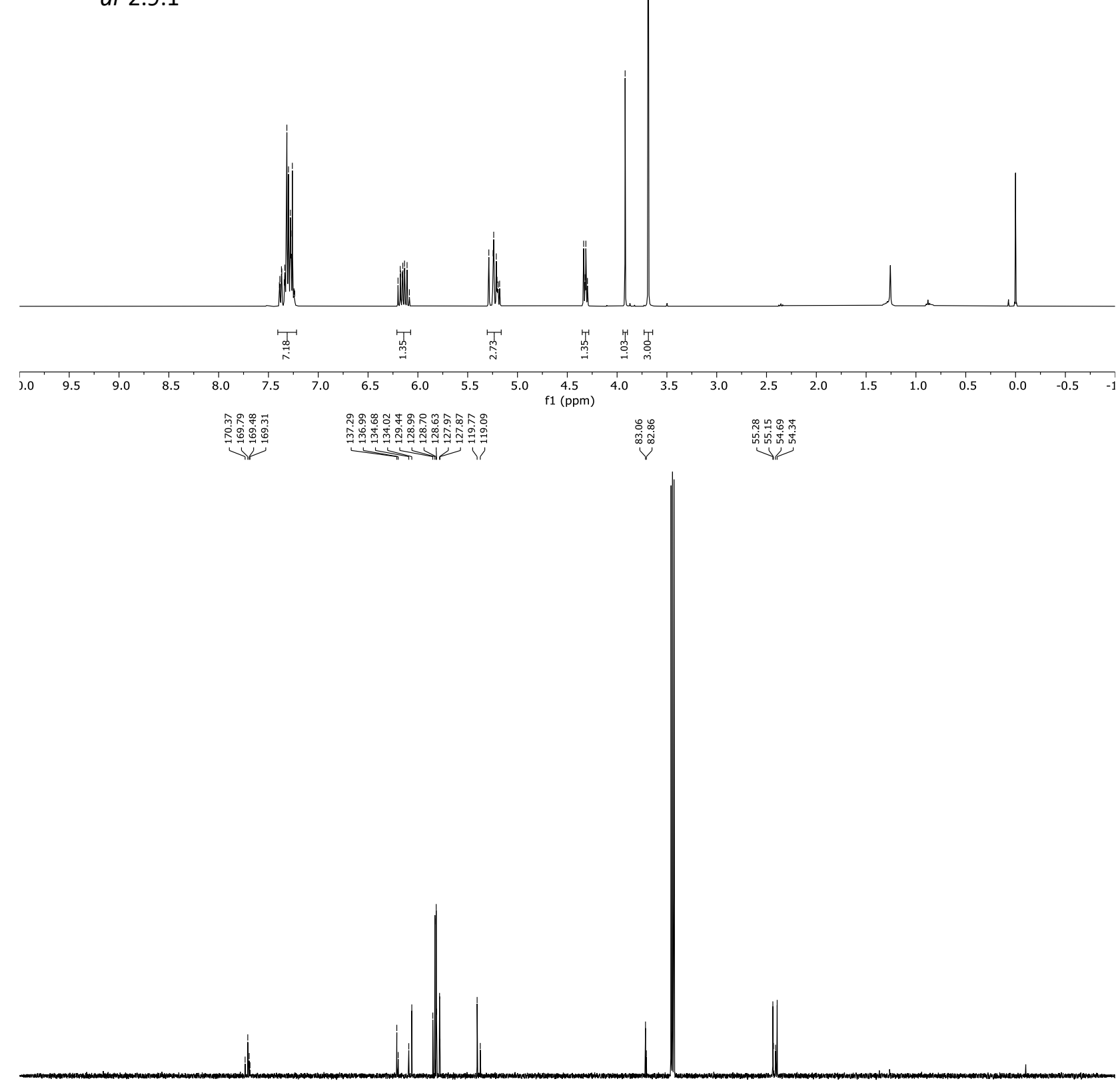

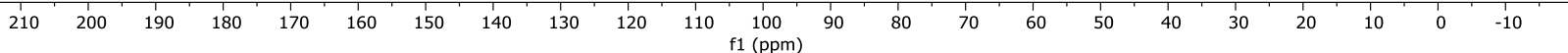


Figure S10. ${ }^{1} \mathrm{H}$ NMR $\left(400 \mathrm{MHz}, \mathrm{CDCl}_{3}\right)$ and ${ }^{13} \mathrm{C} \mathrm{NMR}\left(101 \mathrm{MHz}, \mathrm{CDCl}_{3}\right)$ of $\mathbf{3 b}$
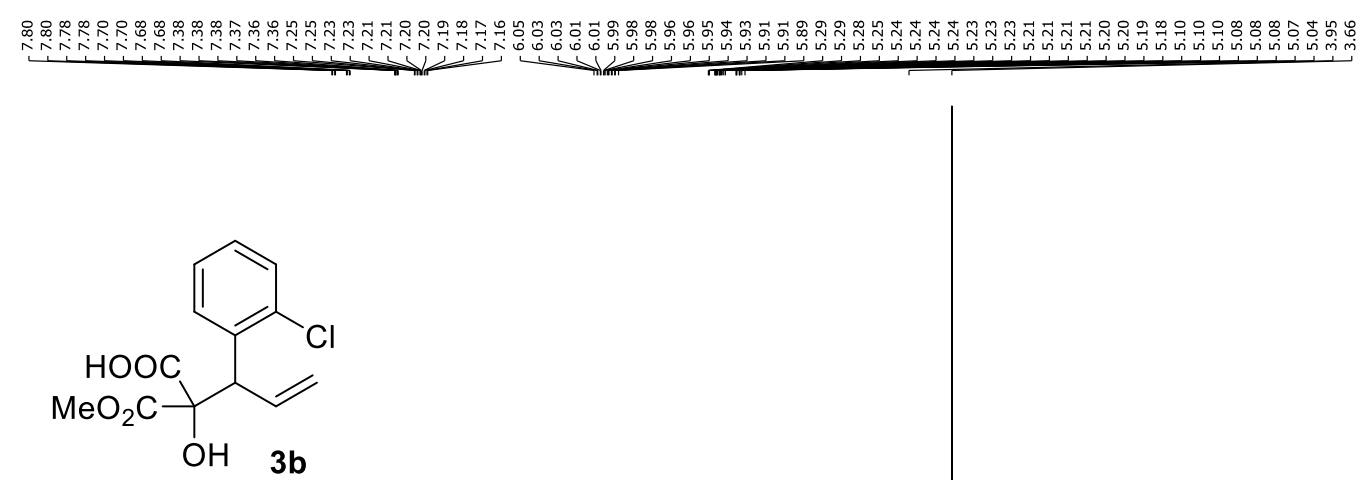

dr 20:1

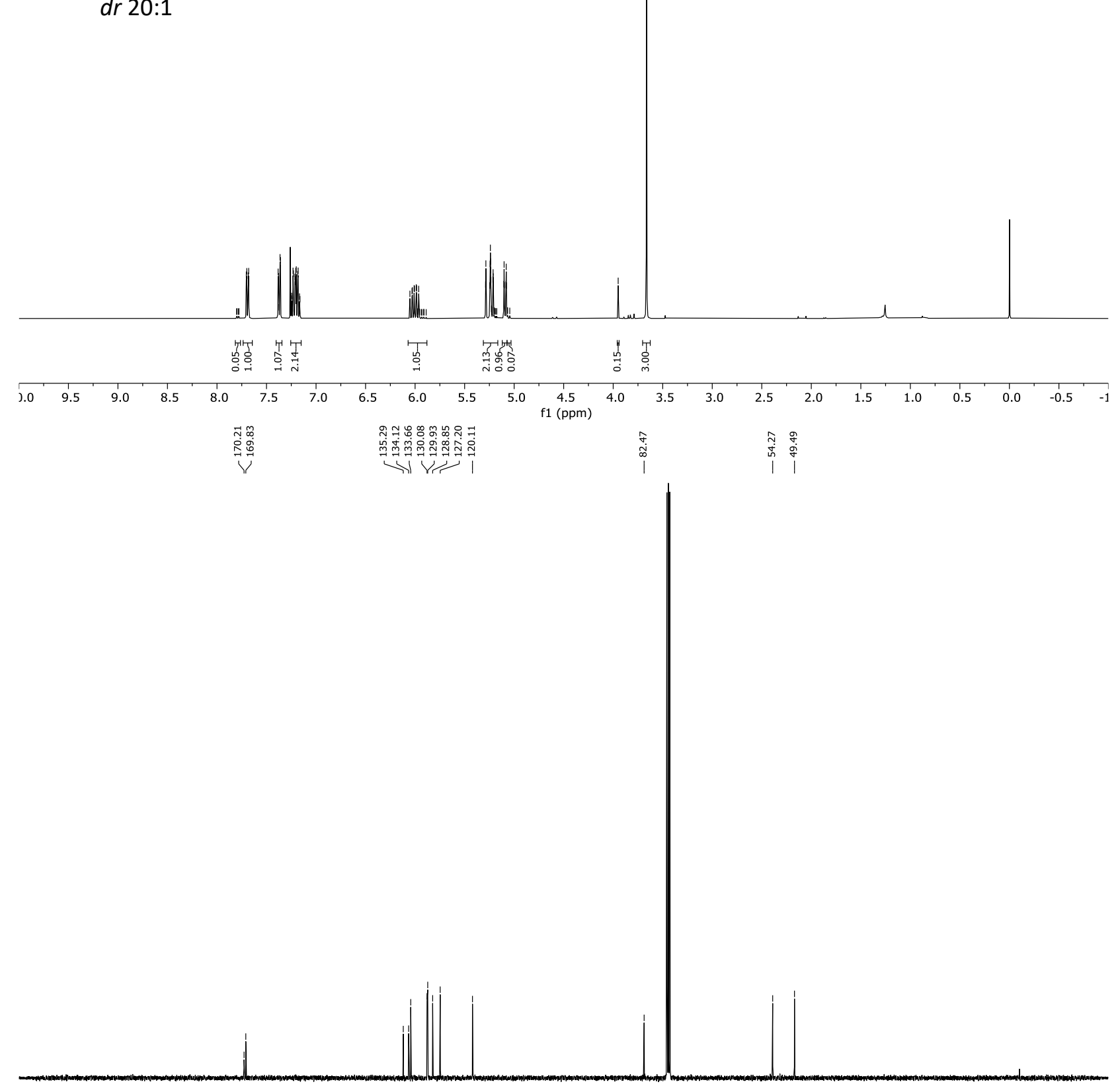

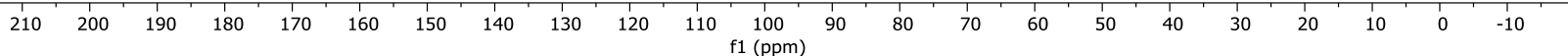


Figure S11. ${ }^{1} \mathrm{H}$ NMR $\left(400 \mathrm{MHz}, \mathrm{CDCl}_{3}\right)$ and $\left.{ }^{13} \mathrm{C} \mathrm{NMR} \mathrm{(101} \mathrm{MHz,} \mathrm{CDCl}_{3}\right)$ of $3 \mathrm{C}$

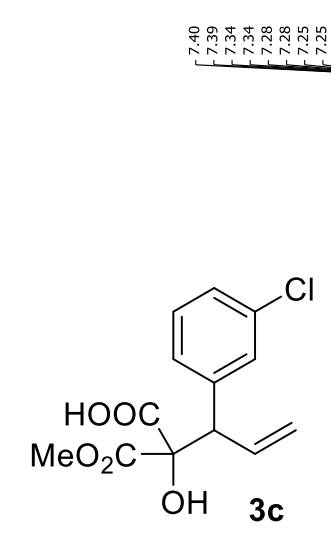

$d r 2.5: 1$
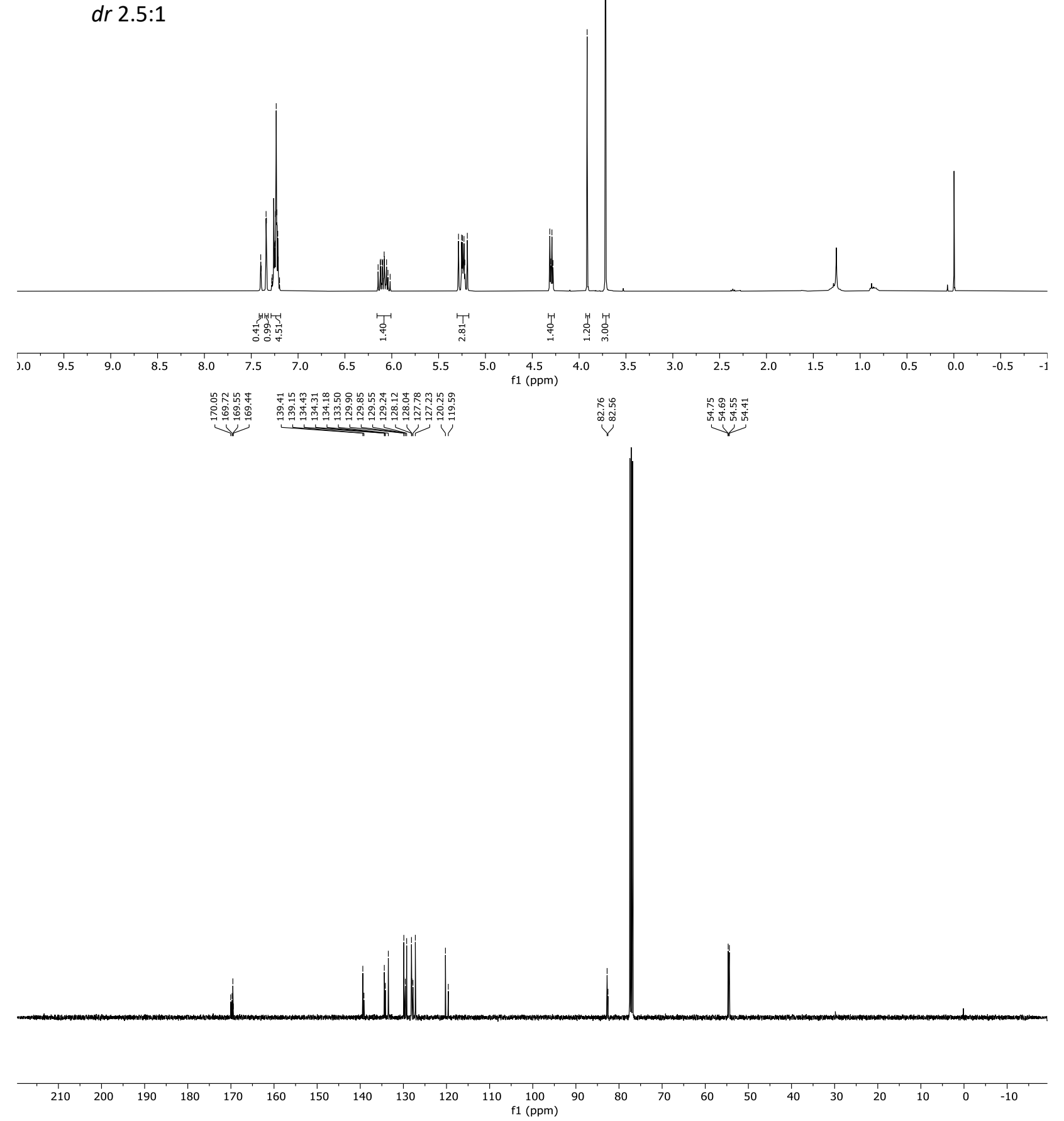
Figure S12. ${ }^{1} \mathrm{H}$ NMR $\left(400 \mathrm{MHz}, \mathrm{CDCl}_{3}\right)$ and ${ }^{13} \mathrm{C} \mathrm{NMR}\left(101 \mathrm{MHz}, \mathrm{CDCl}_{3}\right)$ of $\mathbf{3 d}$
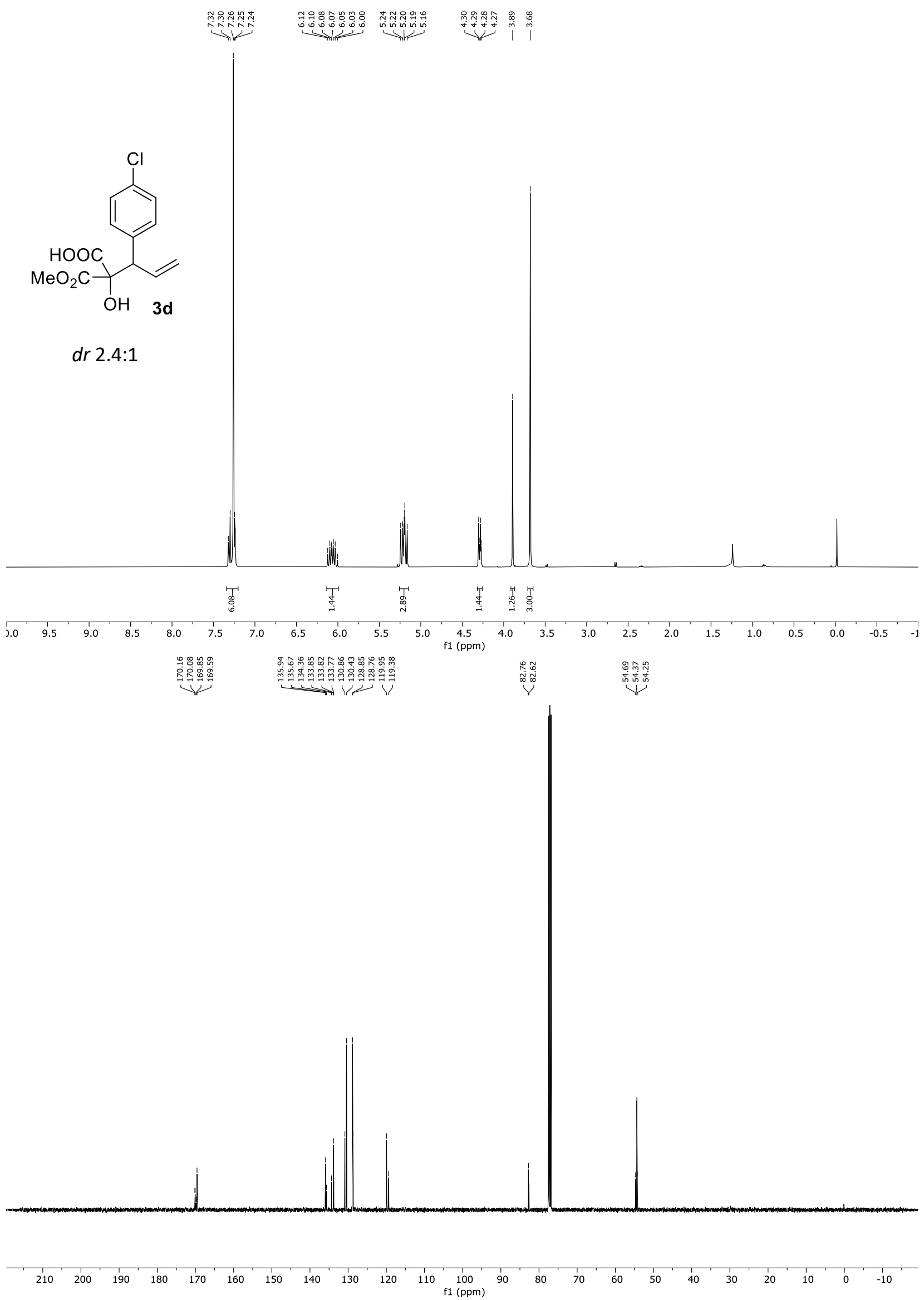
Figure S13. ${ }^{1} \mathrm{H} \mathrm{NMR}\left(400 \mathrm{MHz}, \mathrm{CDCl}_{3}\right)$ and ${ }^{13} \mathrm{C} \mathrm{NMR}\left(101 \mathrm{MHz}, \mathrm{CDCl}_{3}\right)$ of $3 \mathbf{e}$
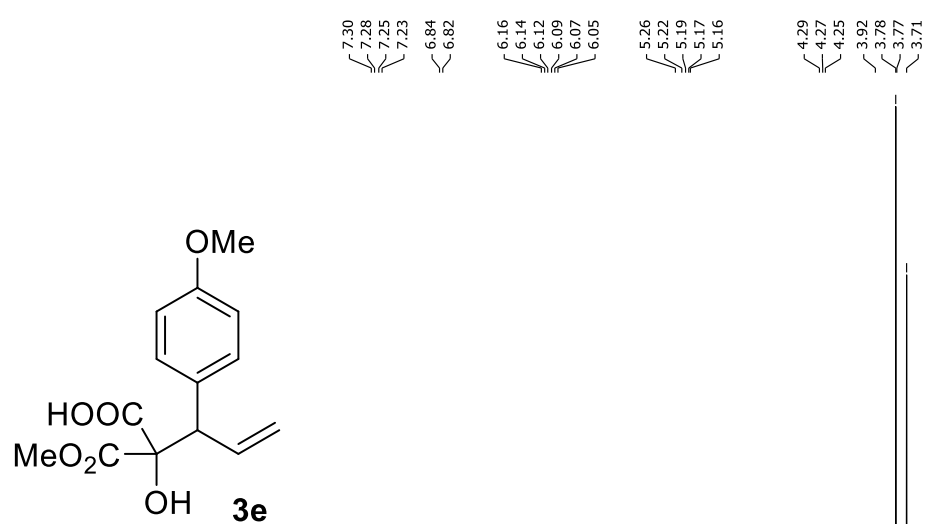

dr 2.5:1
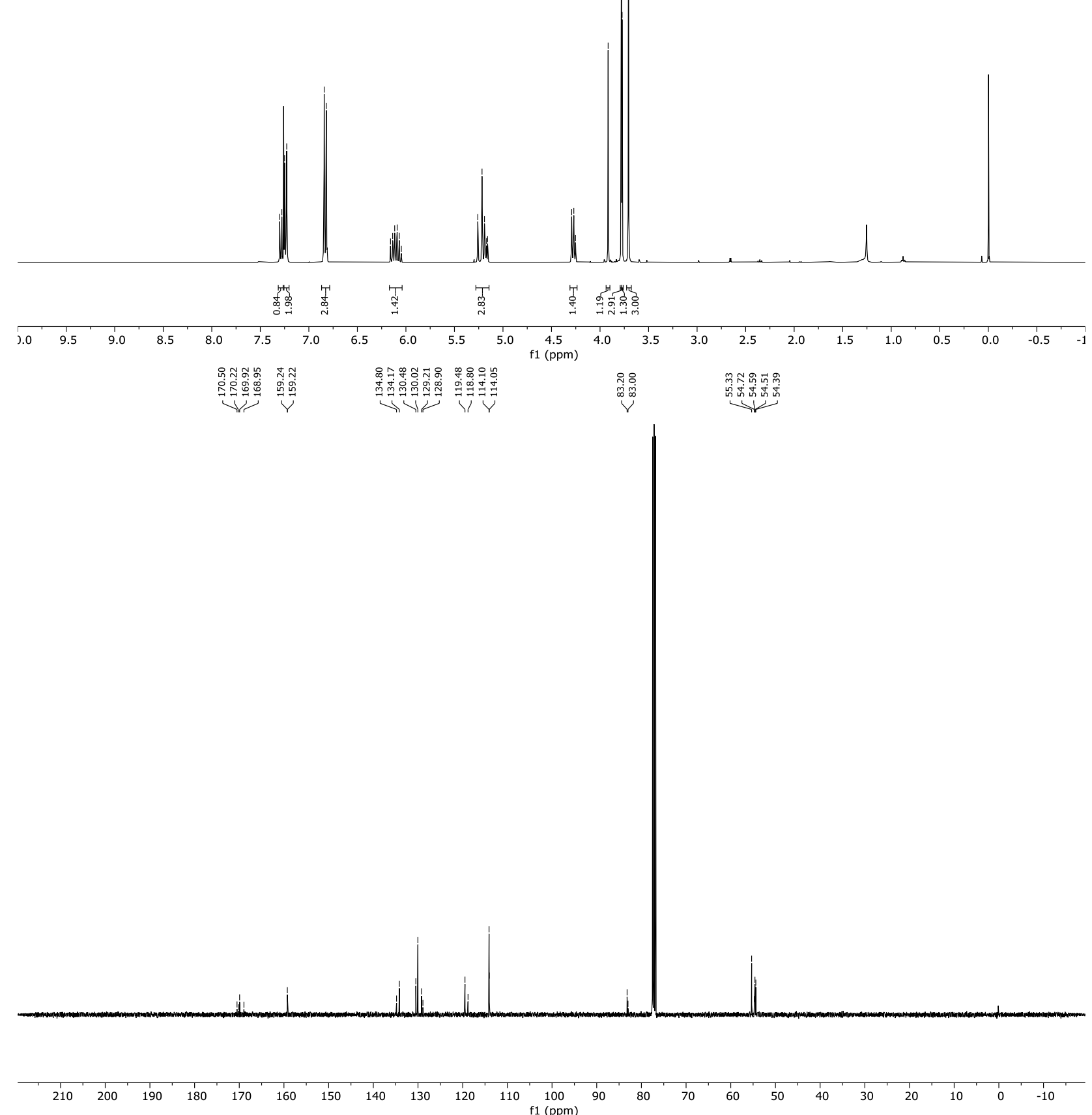
Figure S14. ${ }^{1} \mathrm{H}$ NMR $\left(400 \mathrm{MHz}, \mathrm{CDCl}_{3}\right)$ and ${ }^{13} \mathrm{C} \mathrm{NMR}\left(101 \mathrm{MHz}, \mathrm{CDCl}_{3}\right)$ of $\mathbf{3 f}$
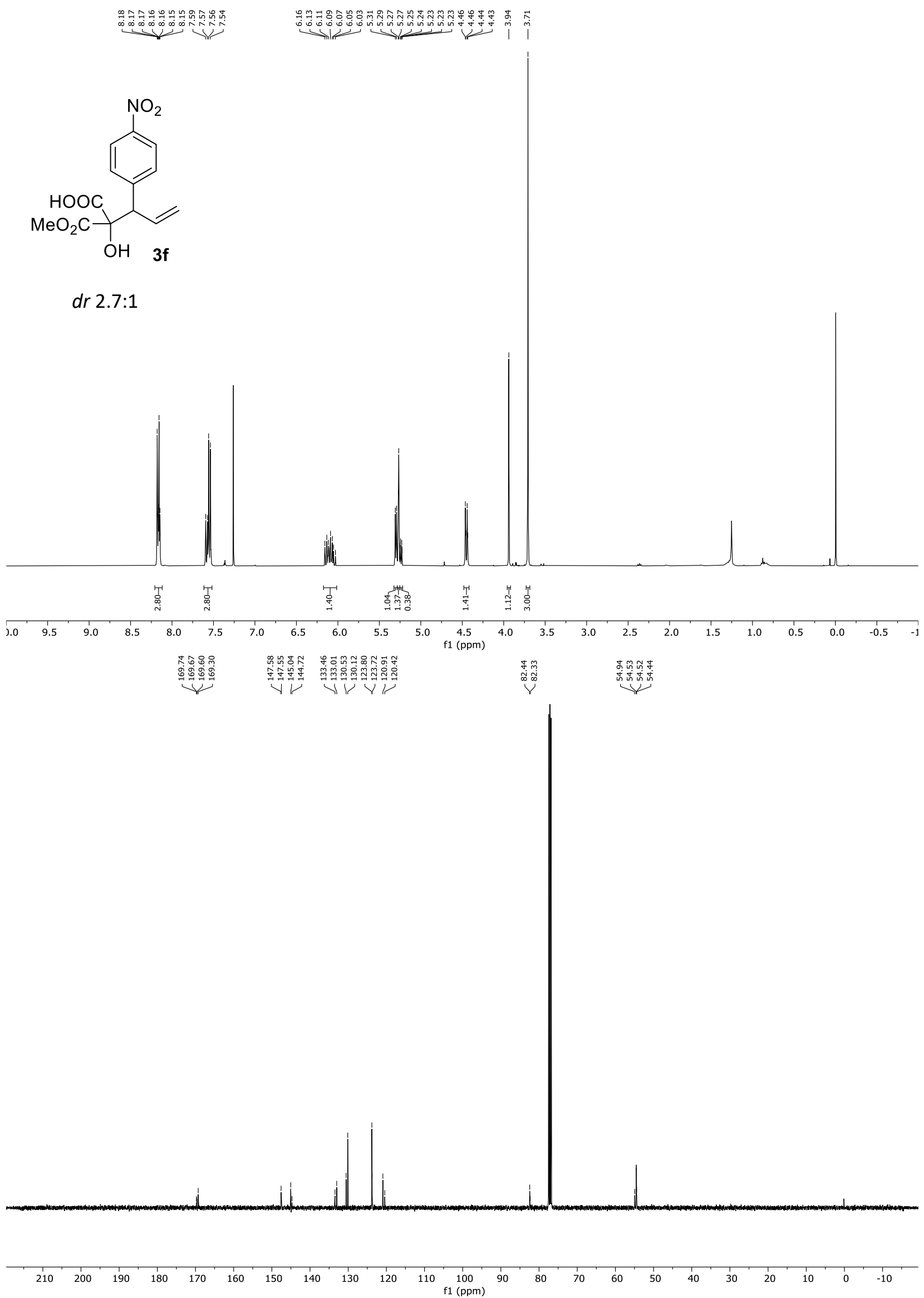
Figure S15. ${ }^{1} \mathrm{H} \mathrm{NMR}\left(400 \mathrm{MHz}, \mathrm{CDCl}_{3}\right)$ and ${ }^{13} \mathrm{C} \mathrm{NMR}\left(101 \mathrm{MHz}, \mathrm{CDCl}_{3}\right)$ of $\mathbf{3 g}$
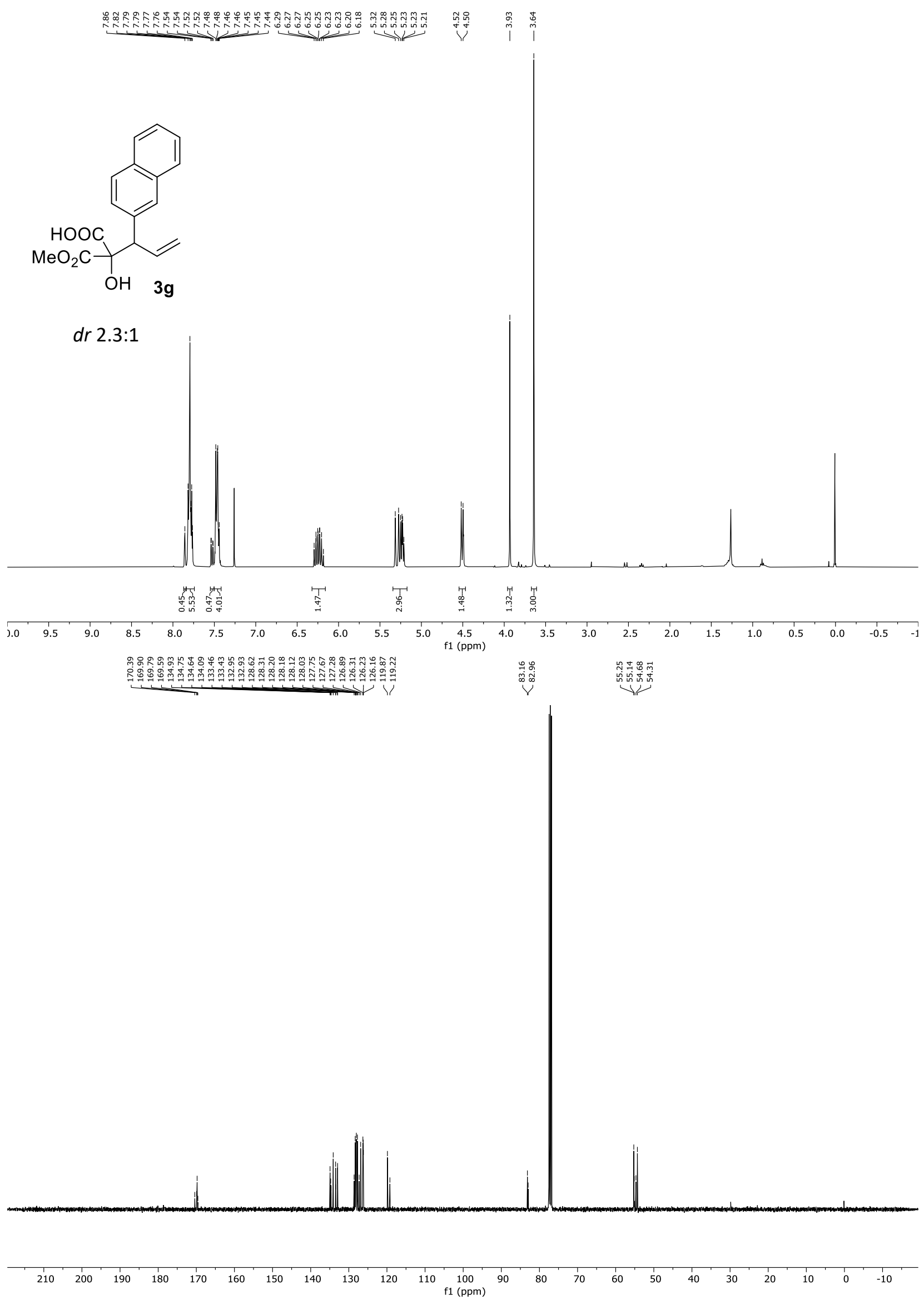
Figure S16. ${ }^{1} \mathrm{H}$ NMR $\left(400 \mathrm{MHz}, \mathrm{CDCl}_{3}\right)$ and ${ }^{13} \mathrm{C} \mathrm{NMR}\left(101 \mathrm{MHz}, \mathrm{CDCl}_{3}\right)$ of $\mathbf{3 h}$
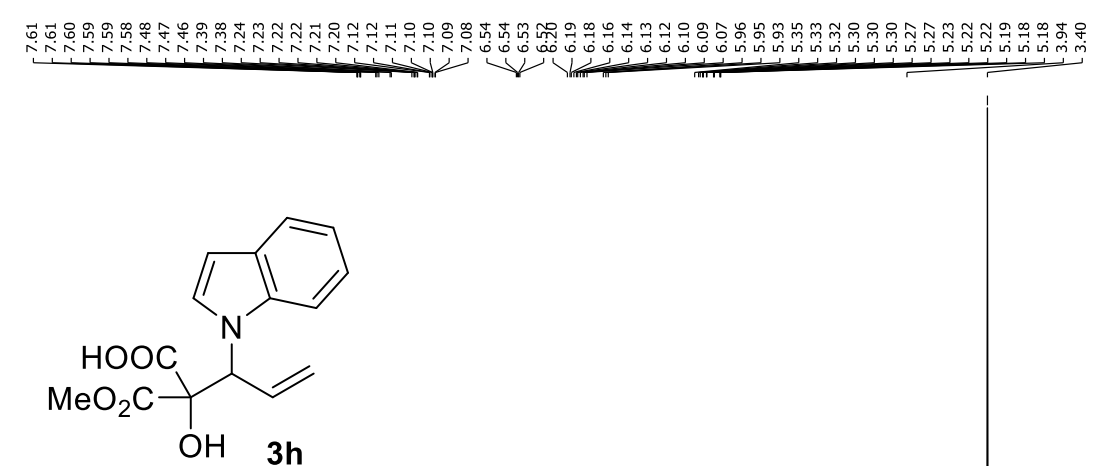

$d r 2.6: 1$
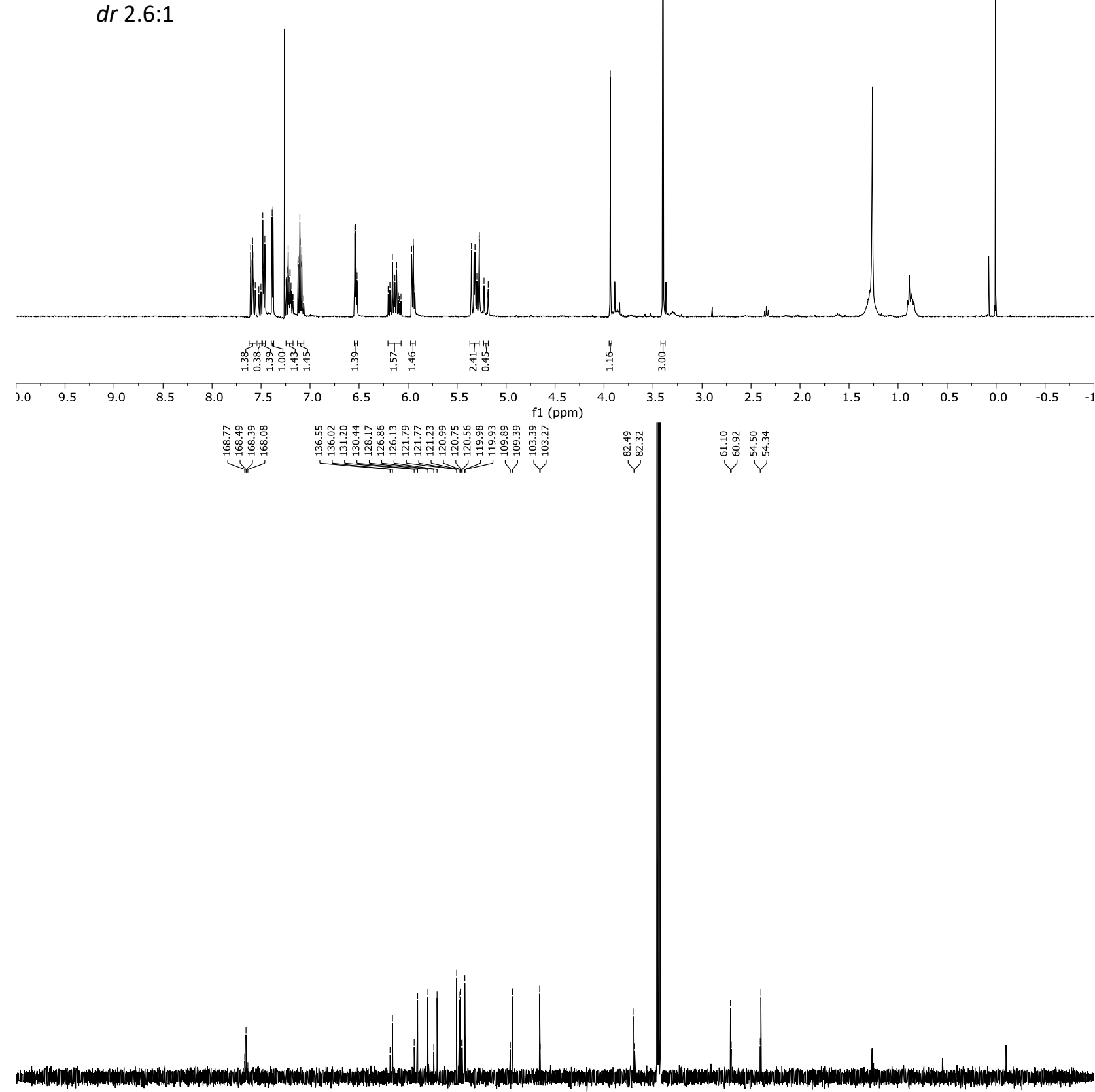

$\begin{array}{lllllllllllllllllllllllll}210 & 200 & 190 & 180 & 170 & 160 & 150 & 140 & 130 & 120 & 110 & 100 & 90 & 80 & 70 & 60 & 50 & 40 & 30 & 20 & 10 & 0 & -10 & \mathrm{f} 1(\mathrm{ppm})\end{array}$ 
Figure S17. ${ }^{1} \mathrm{H} \mathrm{NMR}\left(400 \mathrm{MHz}, \mathrm{CDCl}_{3}\right)$ and ${ }^{13} \mathrm{C} \mathrm{NMR}\left(101 \mathrm{MHz}, \mathrm{CDCl}_{3}\right)$ of $\mathbf{3 i}$

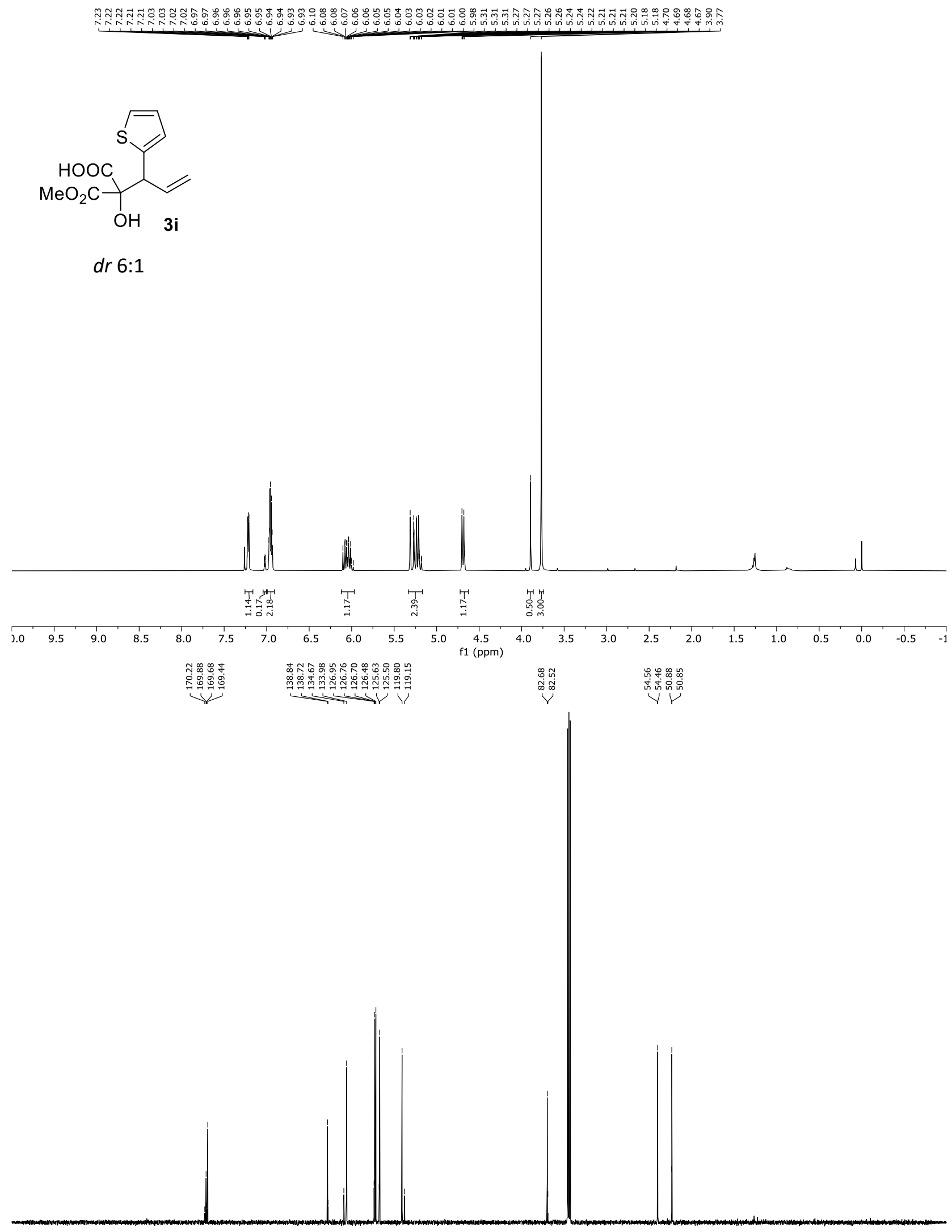

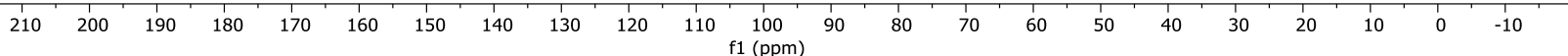


Figure S18. ${ }^{1} \mathrm{H}$ NMR $\left(400 \mathrm{MHz}, \mathrm{CDCl}_{3}\right)$ and ${ }^{13} \mathrm{C} \mathrm{NMR}\left(101 \mathrm{MHz}, \mathrm{CDCl}_{3}\right)$ of $\mathbf{3 j}$

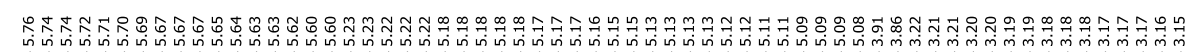

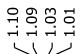

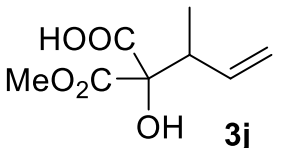

dr 1.4:1
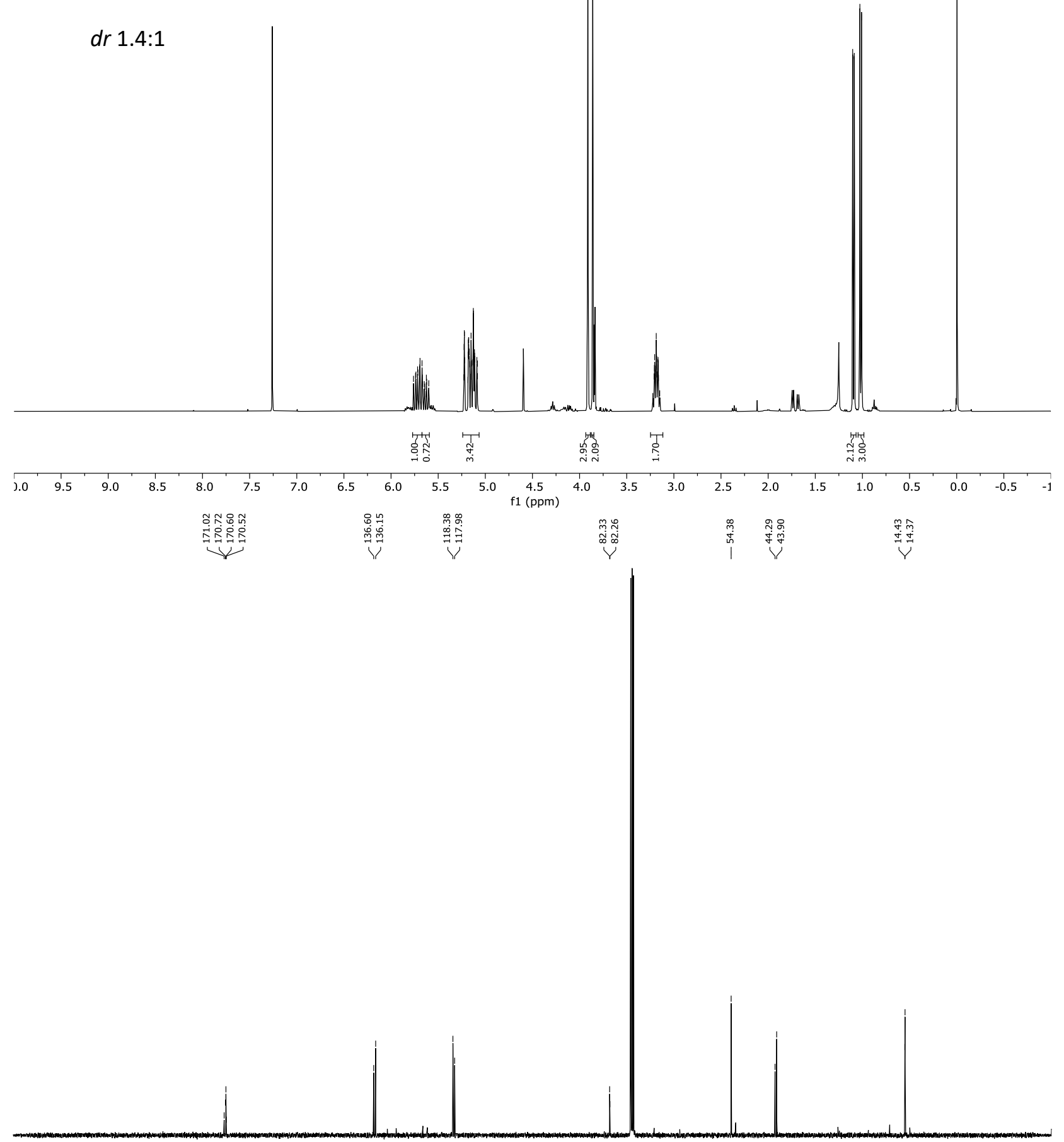

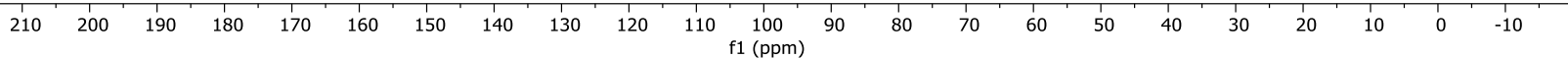


Figure S19. ${ }^{1} \mathrm{H} \mathrm{NMR}\left(400 \mathrm{MHz}, \mathrm{CDCl}_{3}\right)$ and ${ }^{13} \mathrm{C} \mathrm{NMR}\left(101 \mathrm{MHz}, \mathrm{CDCl}_{3}\right)$ of $\mathbf{3 k}$
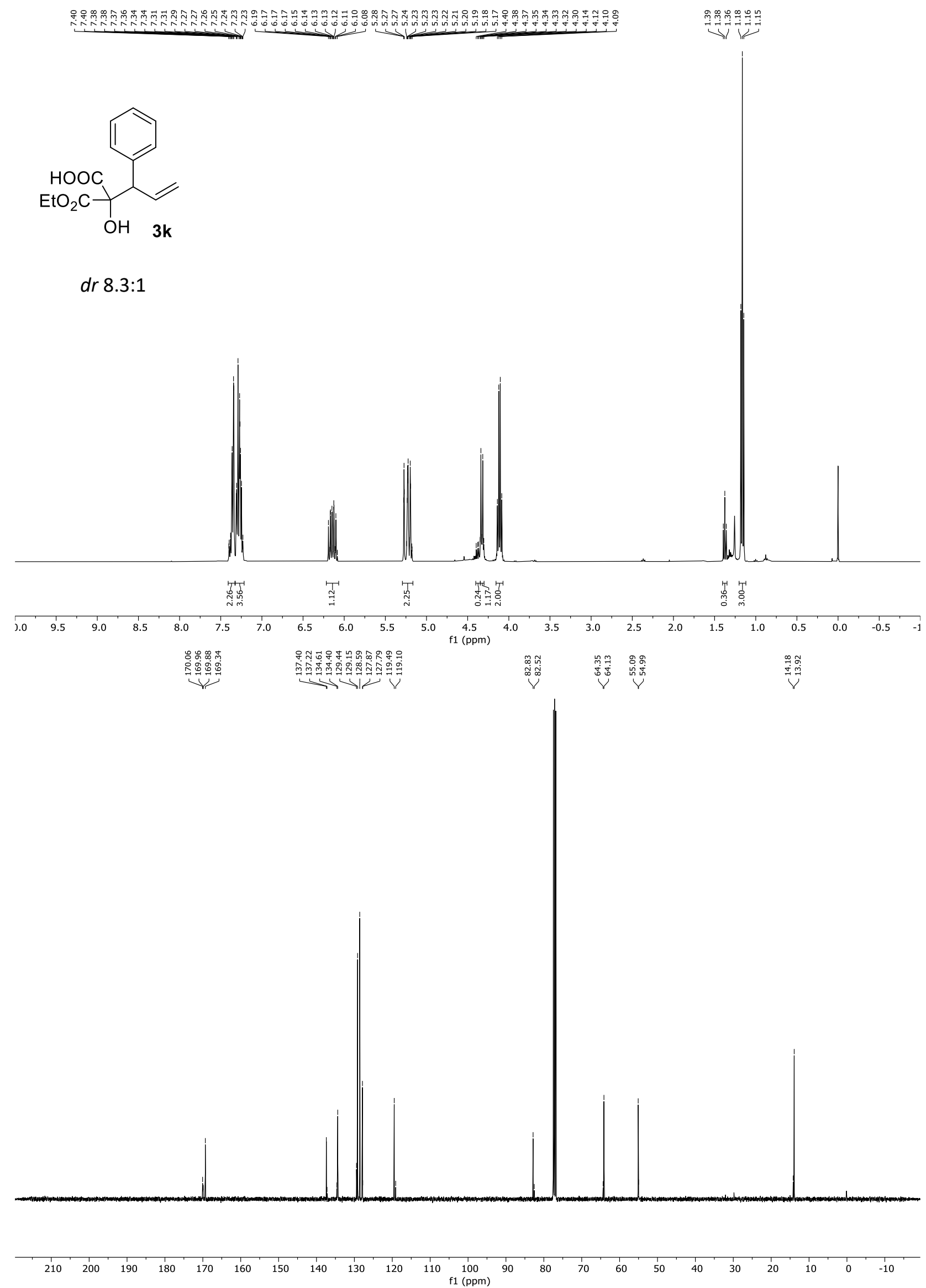
Figure S20. ${ }^{1} \mathrm{H}$ NMR $\left(400 \mathrm{MHz}, \mathrm{CDCl}_{3}\right)$ and ${ }^{13} \mathrm{C} \mathrm{NMR}\left(101 \mathrm{MHz}, \mathrm{CDCl}_{3}\right)$ of major diastereoisomer of $4 a$

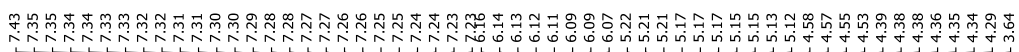<smiles>C=C[C@H](c1ccccc1)C(O)(C(=O)O)C(=O)O[Na]</smiles>
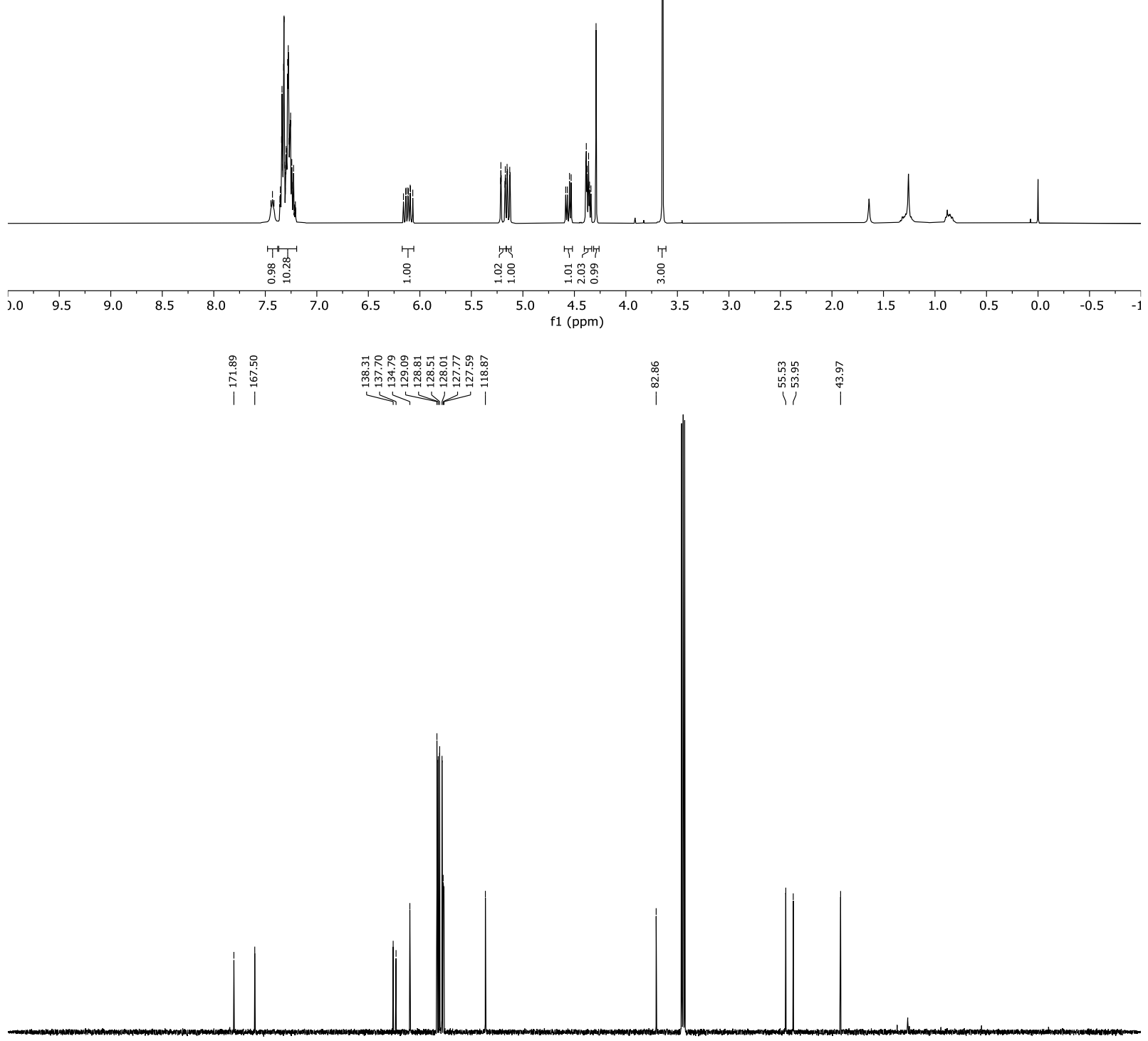

$\begin{array}{llllllllllllllllllllllllll}210 & 200 & 190 & 180 & 170 & 160 & 150 & 140 & 130 & 120 & 110 & 100 & 90 & 80 & 70 & 60 & 50 & 40 & 30 & 20 & 10 & 0 & -10 & 10\end{array}$ 
Figure S21. ${ }^{1} \mathrm{H} \mathrm{NMR}\left(400 \mathrm{MHz}, \mathrm{CDCl}_{3}\right)$ and ${ }^{13} \mathrm{C} \mathrm{NMR}\left(101 \mathrm{MHz}, \mathrm{CDCl}_{3}\right)$ of minor diastereoisomer of 4 a
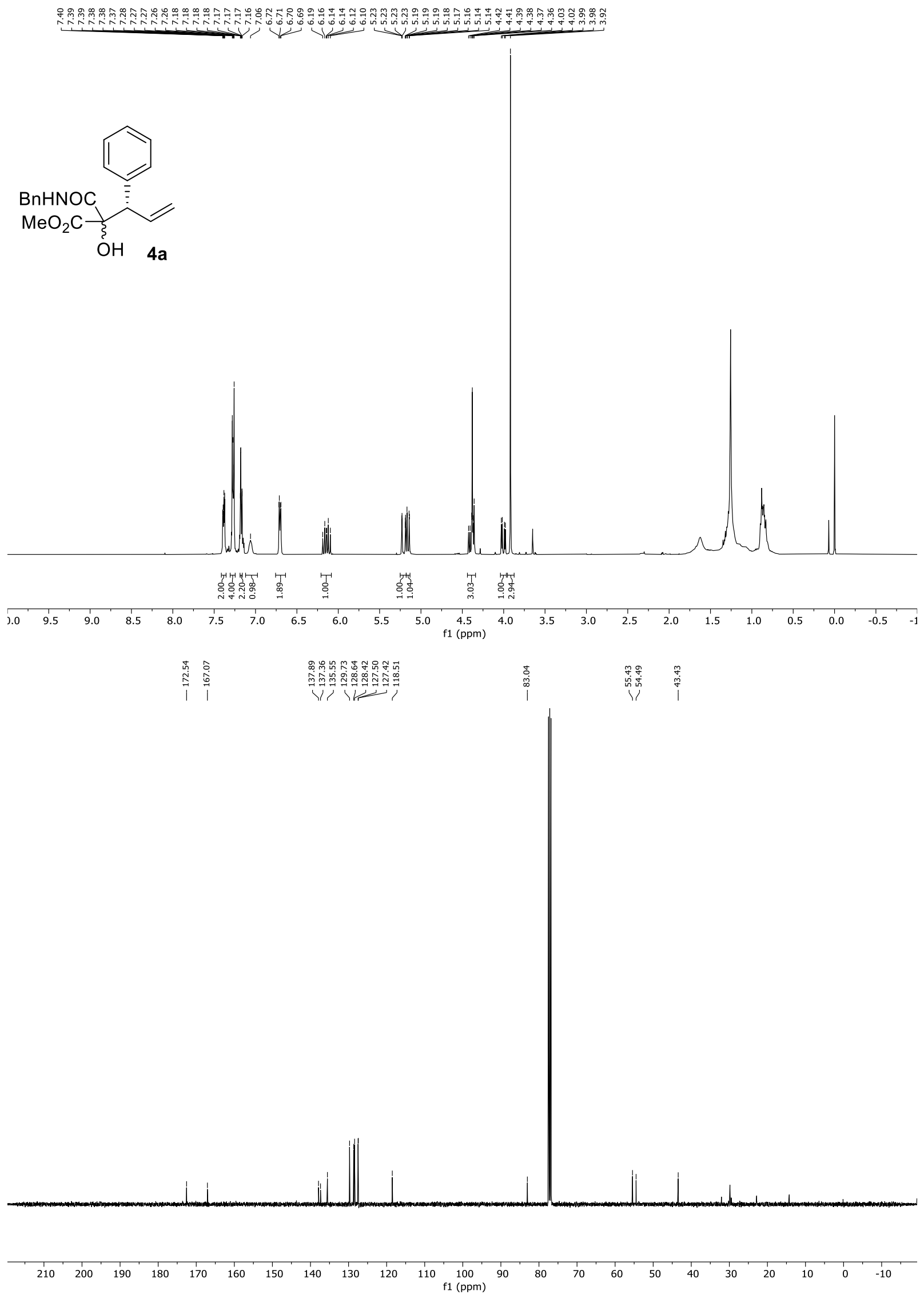
(6) Chiral HPLC chromatograms for compounds 3

Figure S22. HPLC chromatogram of rac-3a

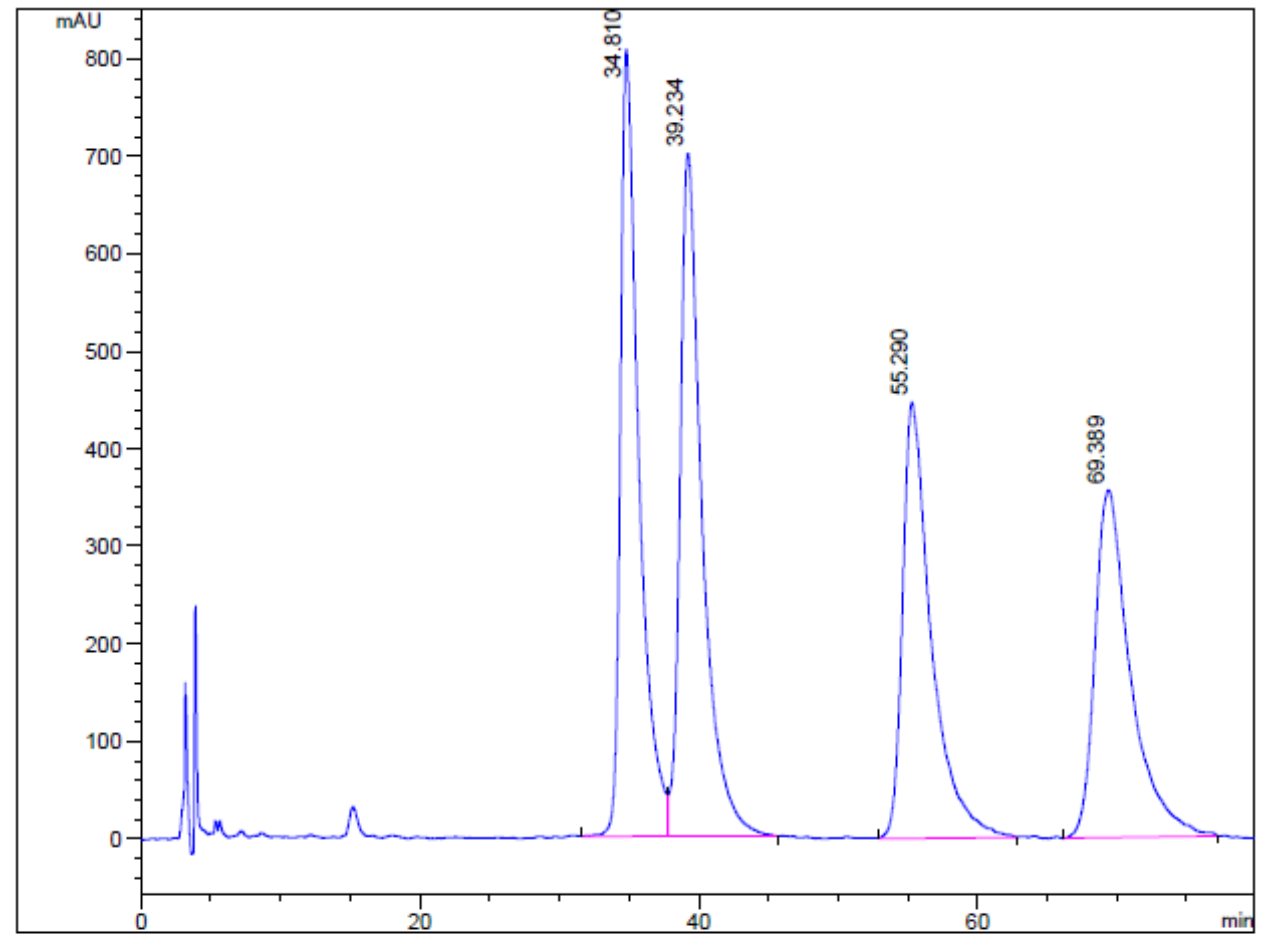

Signal 1: VWD1 A, Wavelength=210 nm

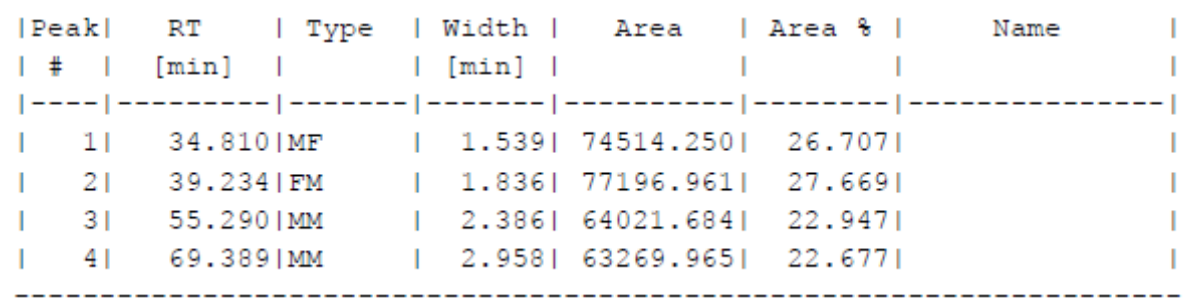


Figure S23. HPLC chromatograms of 3a obtained via (R)-intermediate $\mathbf{2 a}$ and $\mathbf{3 a}$ obtained via $(S)$-intermediate $\mathbf{2 a}$

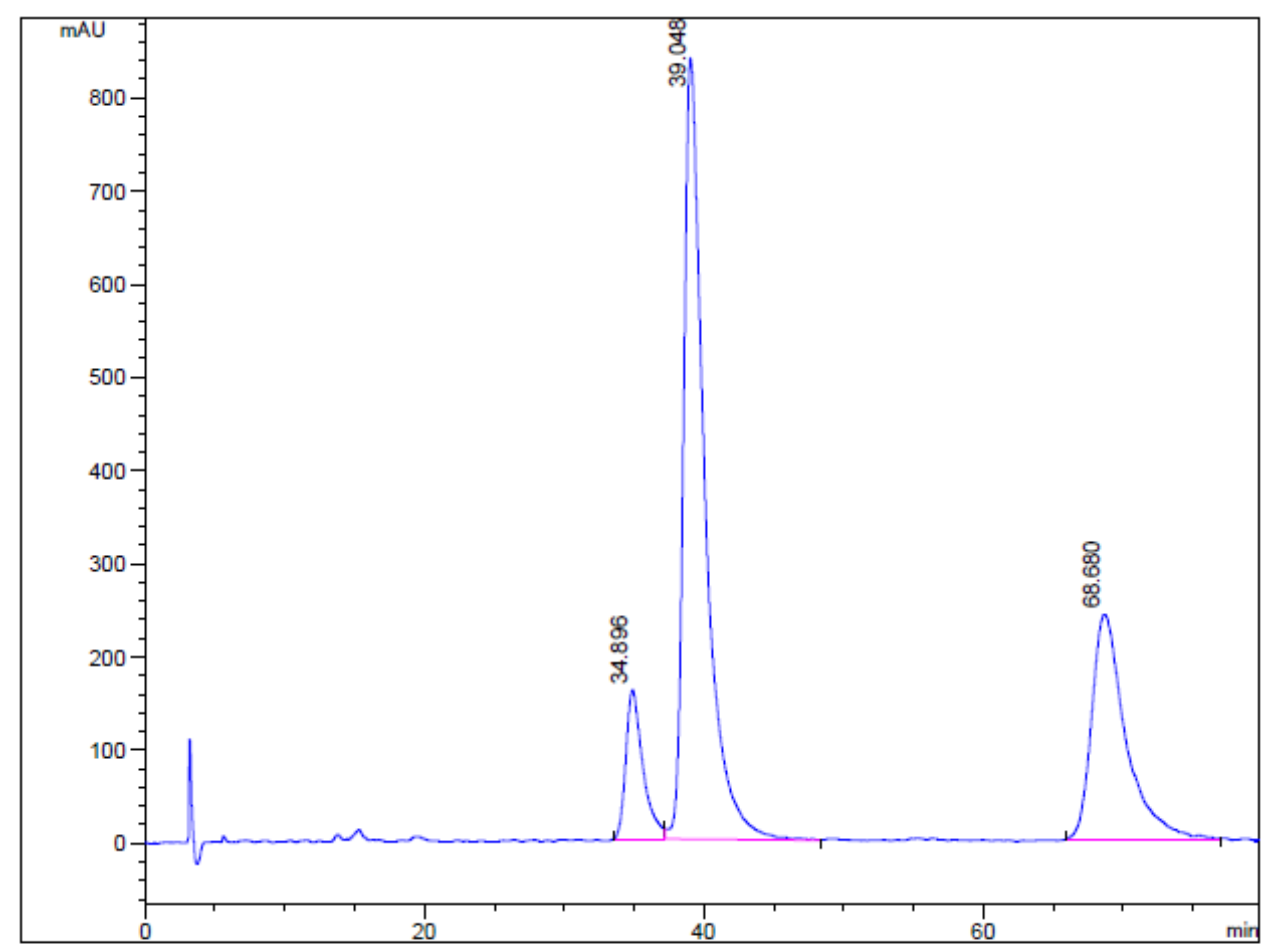

Signal 1: VWD1 A, Wavelength=210 nm

\begin{tabular}{|c|c|c|c|c|c|c|c|c|c|}
\hline \multicolumn{2}{|c|}{ |Peak| } & RT & I Type & I & Width I & Area & I Area \& I & Name & \\
\hline $1 \neq$ & I & [min] & I & I & [min] | & I & I & & T \\
\hline & -1 & -- & $1--$ & & -----1 & $------\mid$ & |------- & & \\
\hline & 11 & 34.8 & $6 / \mathrm{MF}$ & I & $1.426 I$ & 13671.325 & 9.5611 & & \\
\hline & 21 & 39.0 & $8 \mid \mathrm{FM}$ & I & $1.759 \mid$ & 88482.0231 & $61.878 \mid$ & & \\
\hline & 31 & 68.6 & $01 \mathrm{MM}$ & 1 & 2.8211 & $40840.828 \mid$ & | $28.561 \mid$ & & \\
\hline
\end{tabular}

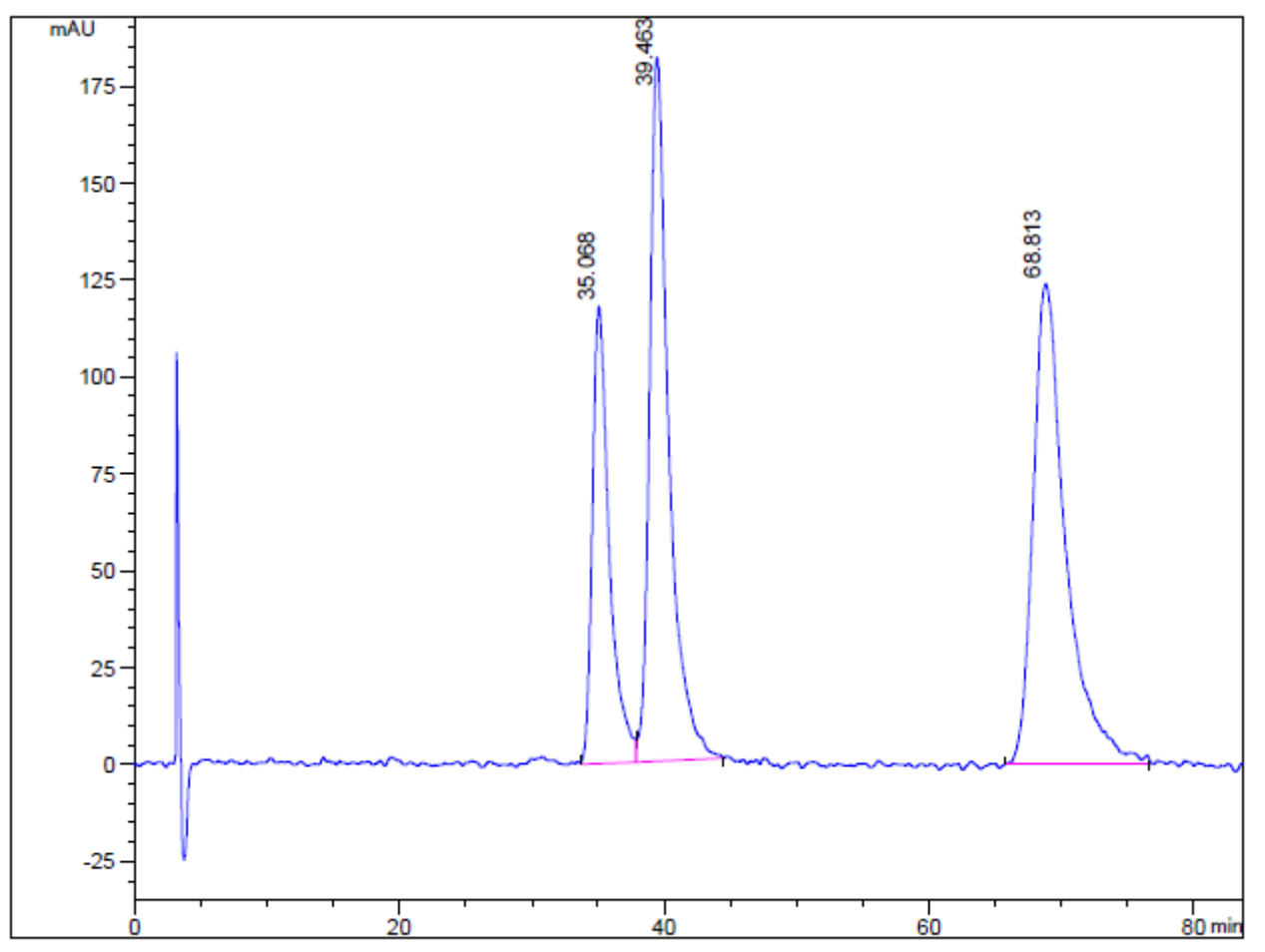

Signal 1: VWD1 A, Wavelength=210 nm

\begin{tabular}{|c|c|c|c|c|c|c|c|}
\hline |Peak| & I Type & I & Width | & Area & Area \& 1 & Name & । \\
\hline | $\#$ | & {$[\mathrm{min}]$} & 1 & [min] | & । & I & & I \\
\hline----1 & $-----1--$ & $-1-$ & $----1-$ & ------- | & $-------\mid$ & & -1 \\
\hline 11 & $35.068 \mid \mathrm{MF}$ & 1 & 1.4851 & 10519.3001 & 20.9631 & & । \\
\hline 21 & $39.463 \mid \mathrm{FM}$ & 1 & $1.687 \mid$ & 18383.2251 & $36.634 \mid$ & & 1 \\
\hline 31 & $68.813 / \mathrm{MM}$ & I & 2.8611 & 21278.1801 & 42.4031 & & I \\
\hline
\end{tabular}


Figure S24. HPLC chromatograms of rac-3b and 3b
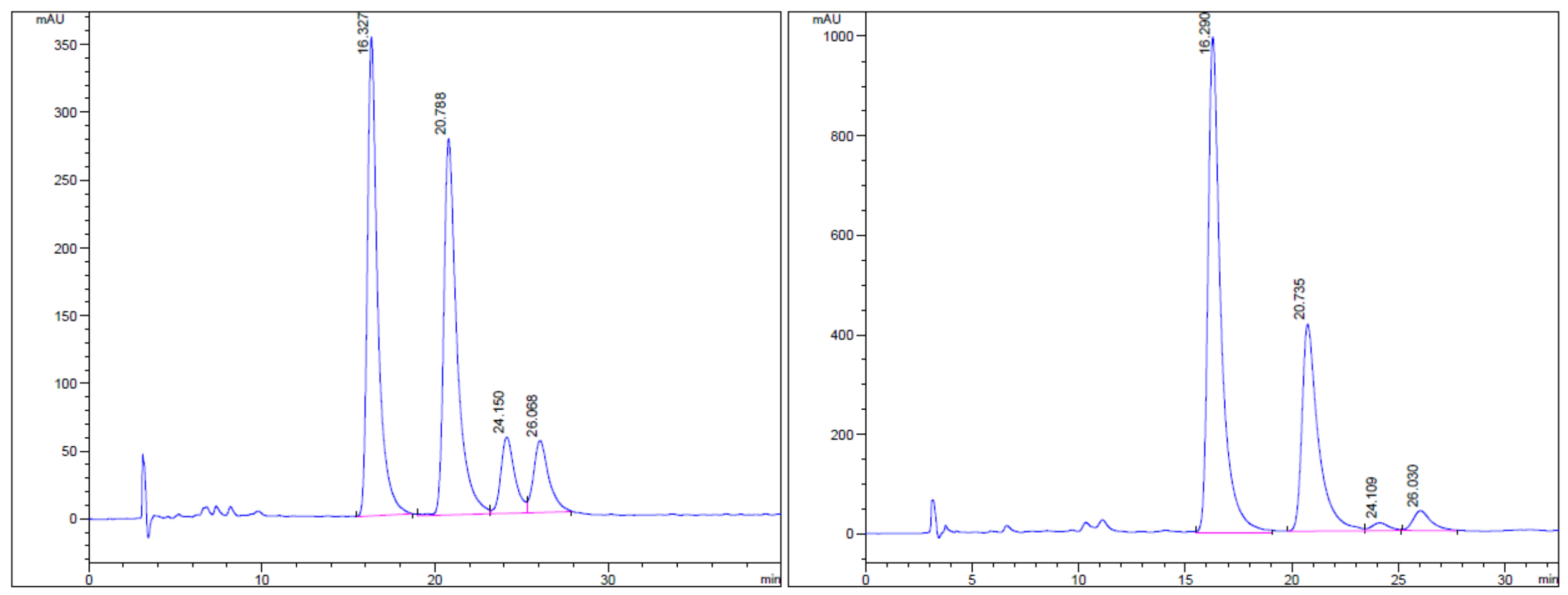

Signal 1: VWD1 A, Wavelength=210 nm

Signal 1: VWD1 A, Wavelength=210 nm

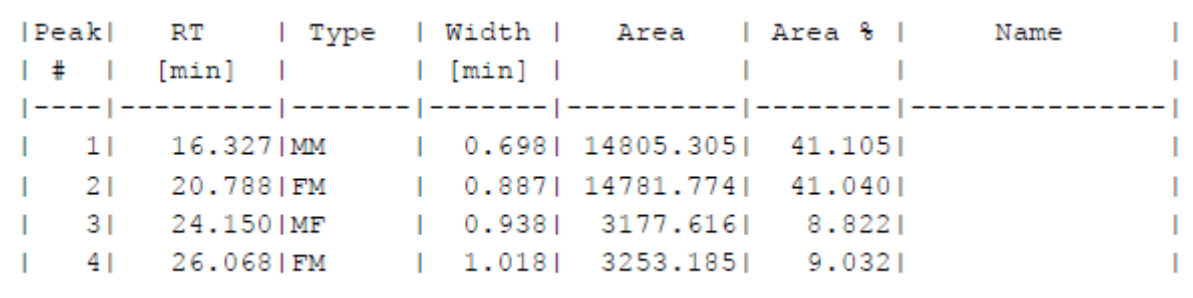

\begin{tabular}{|c|c|c|c|c|c|c|c|c|c|}
\hline \multicolumn{2}{|c|}{ |Peak| } & RT & I Type & I & Width | & Area & Area \& 1 & Name & I \\
\hline I & I & {$[\mathrm{min}]$} & I & I & [min] | & I & I & & 1 \\
\hline & -1 & ---- & $1--$ & $-1-$ & $--1-$ & $---------\mid$ & ---- & & \\
\hline I & 11 & 16.29 & $0 \mid \mathrm{MM}$ & I & 0.7081 & 42360.0661 & 62.6031 & & । \\
\hline I & 21 & 20.73 & $5 \mid \mathrm{MF}$ & 1 & 0.8861 & 22104.9181 & 32.6681 & & I \\
\hline 1 & 31 & 24.10 & $9 \mid \mathrm{FM}$ & I & 0.9091 & 861.0681 & $1.273 \mid$ & & I \\
\hline । & 41 & 26.03 & $0 \mid \mathrm{MM}$ & । & 0.9861 & 2338.6381 & 3.4561 & & । \\
\hline
\end{tabular}


Figure S25. HPLC chromatograms of rac-3c and 3c
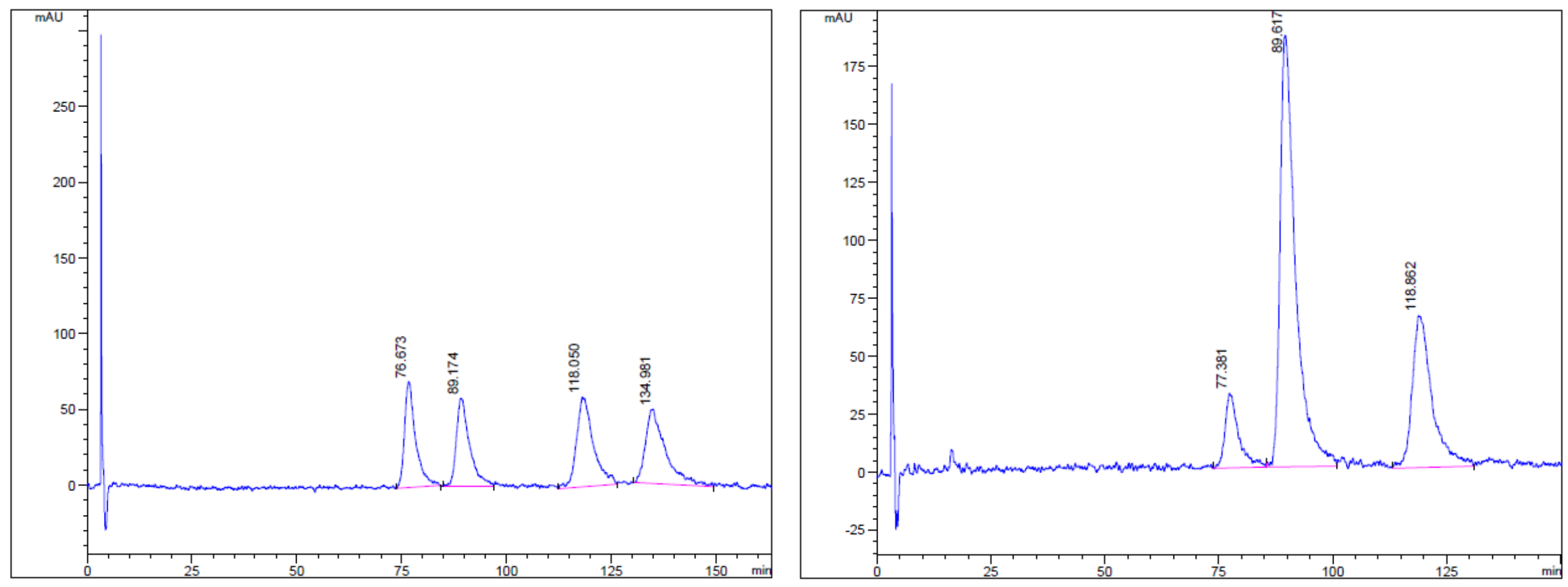

Signal 1: VWD1 A, Wavelength $=210 \mathrm{~nm}$

Signal 1: VWD1 A, Wavelength=210 nm

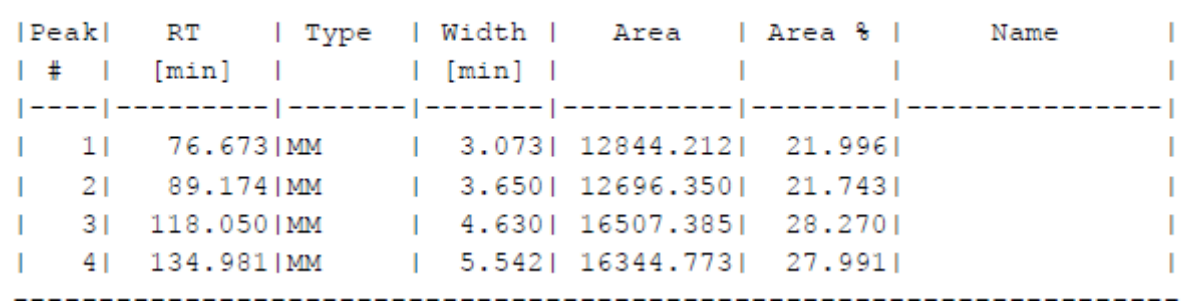

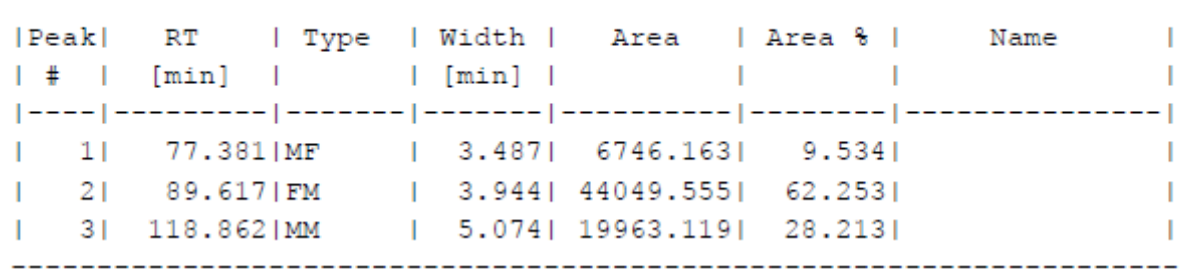


Figure S26. HPLC chromatograms of rac-3d and 3d
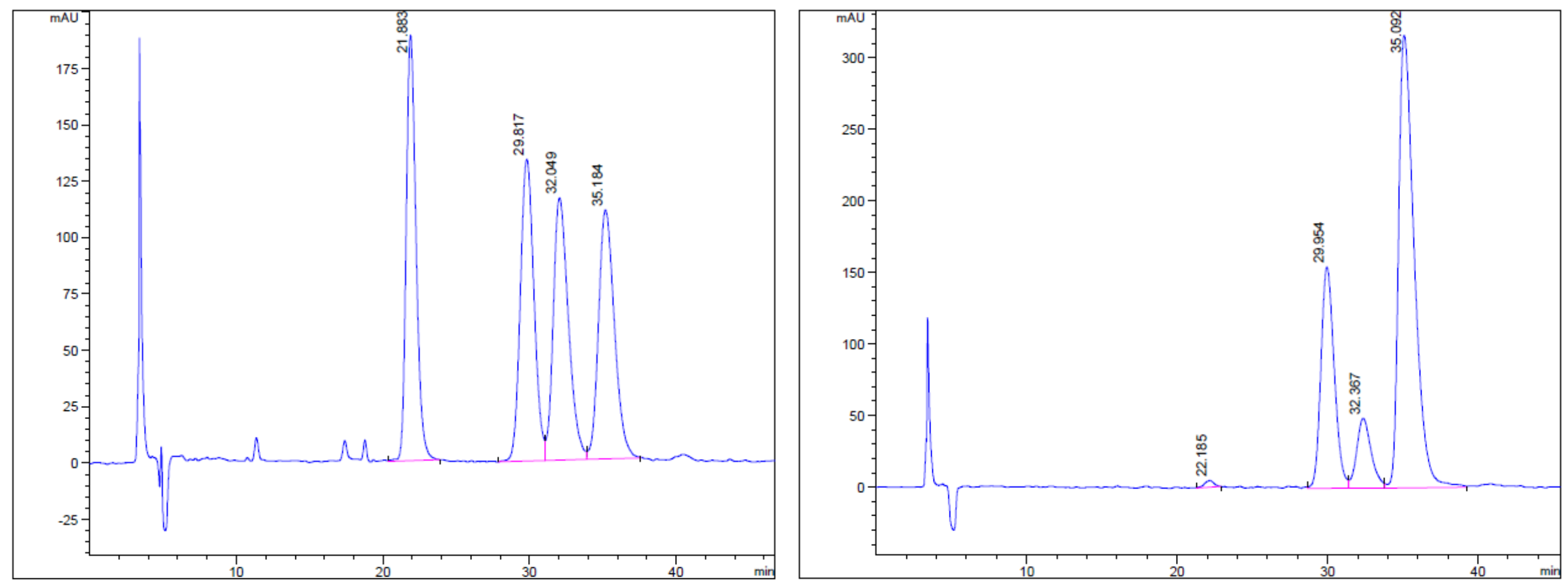

Signal 1: MWD1 C, Sig=210,8 Ref $=360,100$

Signal 1: MWD1 C, Sig $=210,8$ Ref $=360,100$

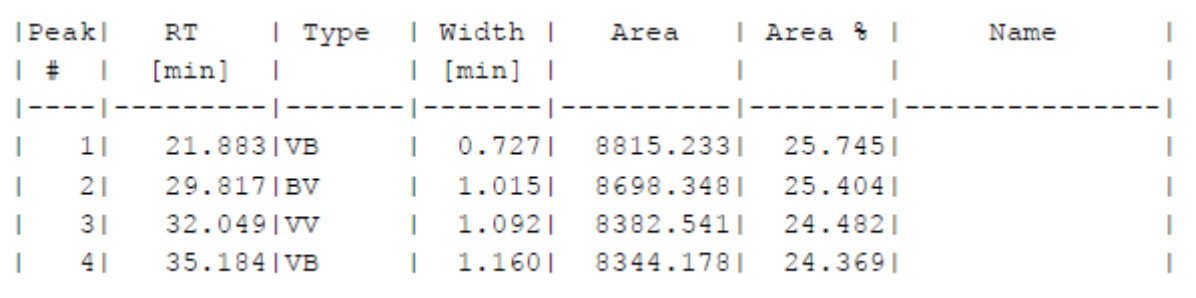

\begin{tabular}{|c|c|c|c|c|c|c|c|c|c|}
\hline \multicolumn{2}{|c|}{ |Peak| } & RT & I Type & I & Width I & Area & Area \& 1 & Name & I \\
\hline $1 \neq$ & I & [min] & I & I & [min] | & I & I & & I \\
\hline $1--$ & $--1-$ & --- & |-- & $-1-$ & $------\mid$ & -------1 & $-------\mid$ & & \\
\hline 1 & 11 & 22.1 & $85 \mid \mathrm{MM}$ & I & 0.7441 & 209.8611 & 0.5831 & & । \\
\hline . & 21 & 29.9 & $54 \mid \mathrm{MF}$ & । & 1.0291 & $9540.994 \mid$ & 26.4861 & & । \\
\hline । & 31 & 32.3 & $57 \mid \mathrm{MF}$ & I & 1.1201 & 3272.2301 & 9.0841 & & । \\
\hline . & 41 & 35.0 & $92 \mid \mathrm{FM}$ & I & 1.2131 & 23000.3091 & 63.8481 & & | \\
\hline
\end{tabular}


Figure S27. HPLC chromatograms of rac-3e and $\mathbf{3 e}$

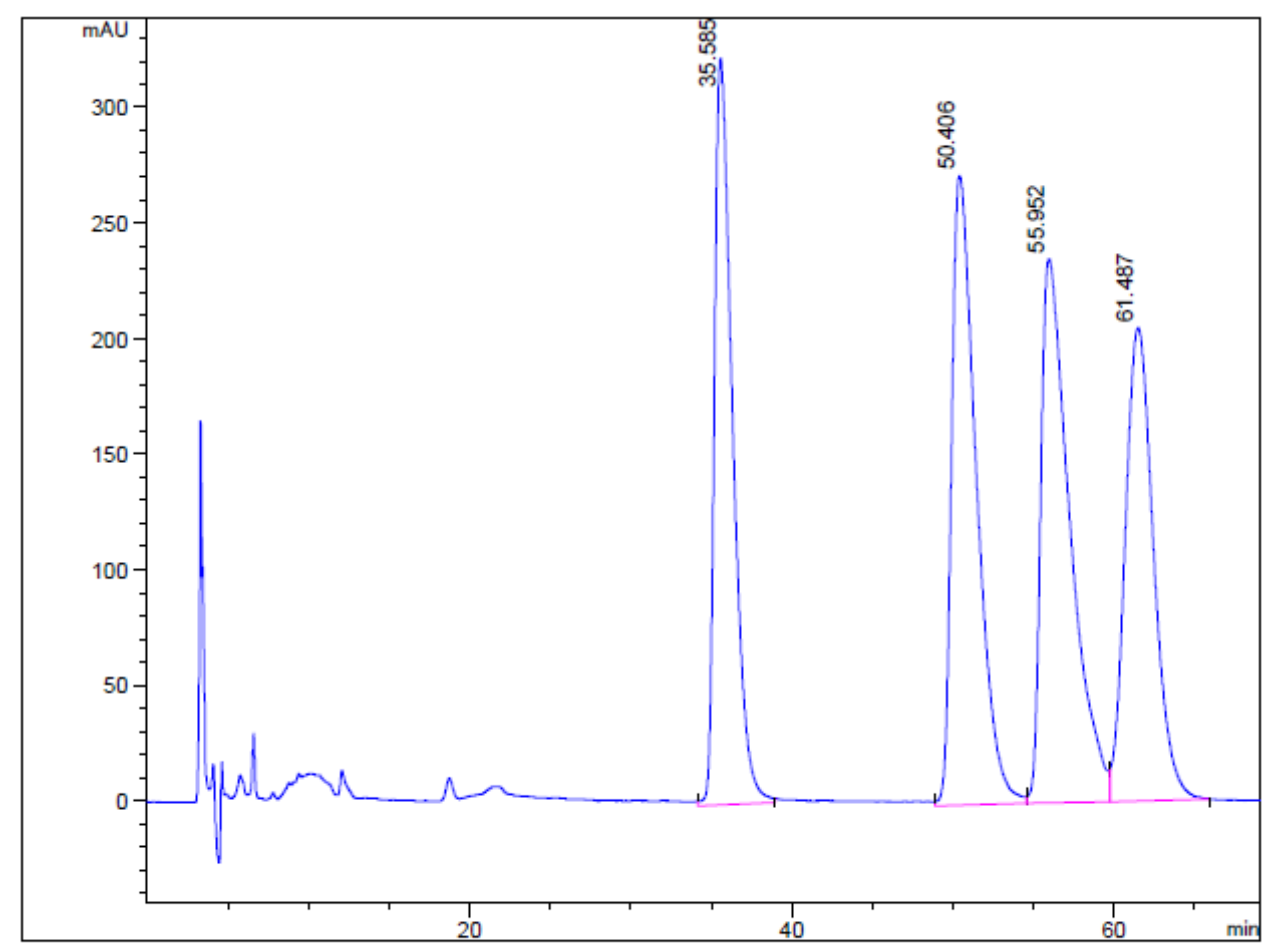

Signal 1: MWD1 C, Sig=210,8 Ref $=360,100$

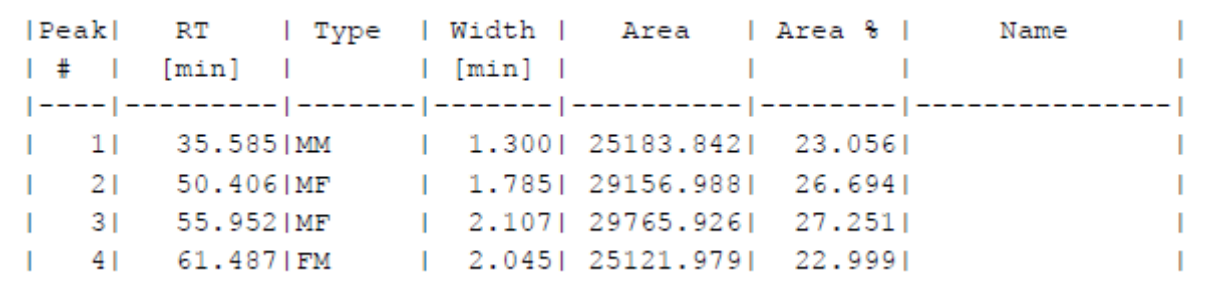

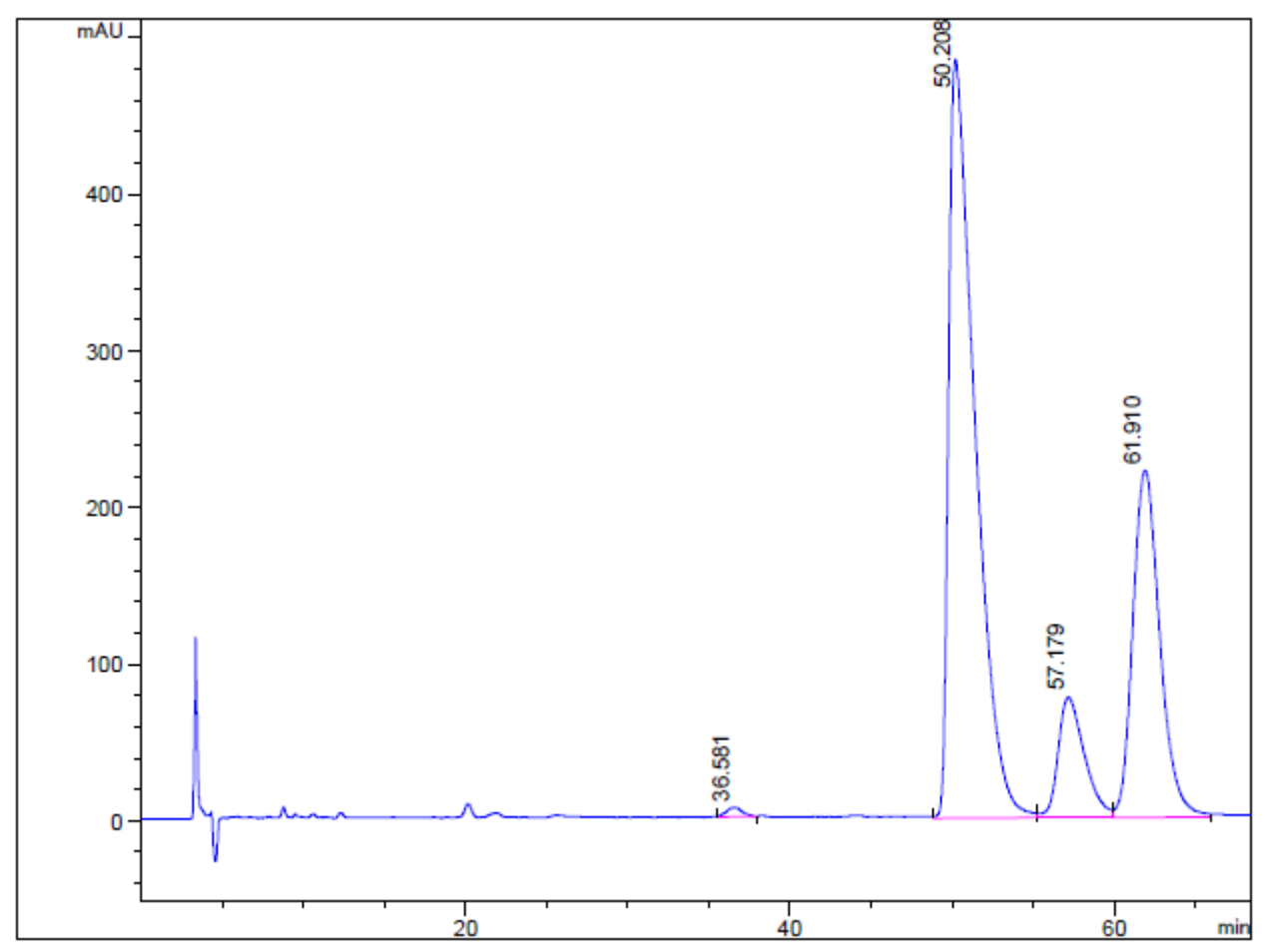

Signal 1: MWD1 C, Sig=210, 8 Ref $=360,100$

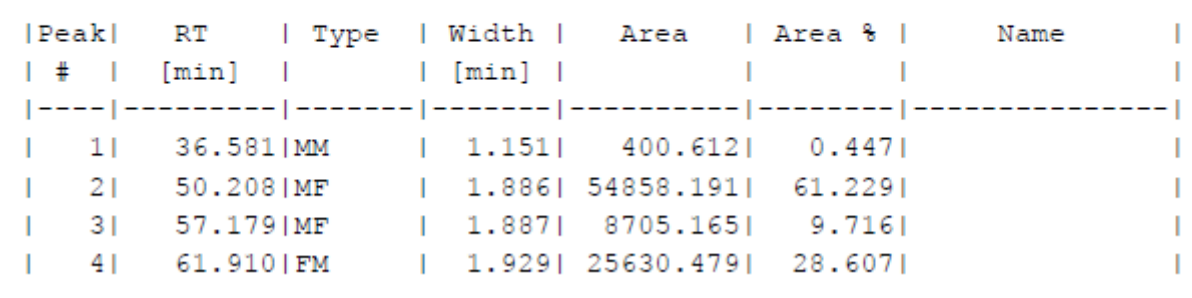


Figure S28. HPLC chromatograms of rac-3f and $\mathbf{3 f}$
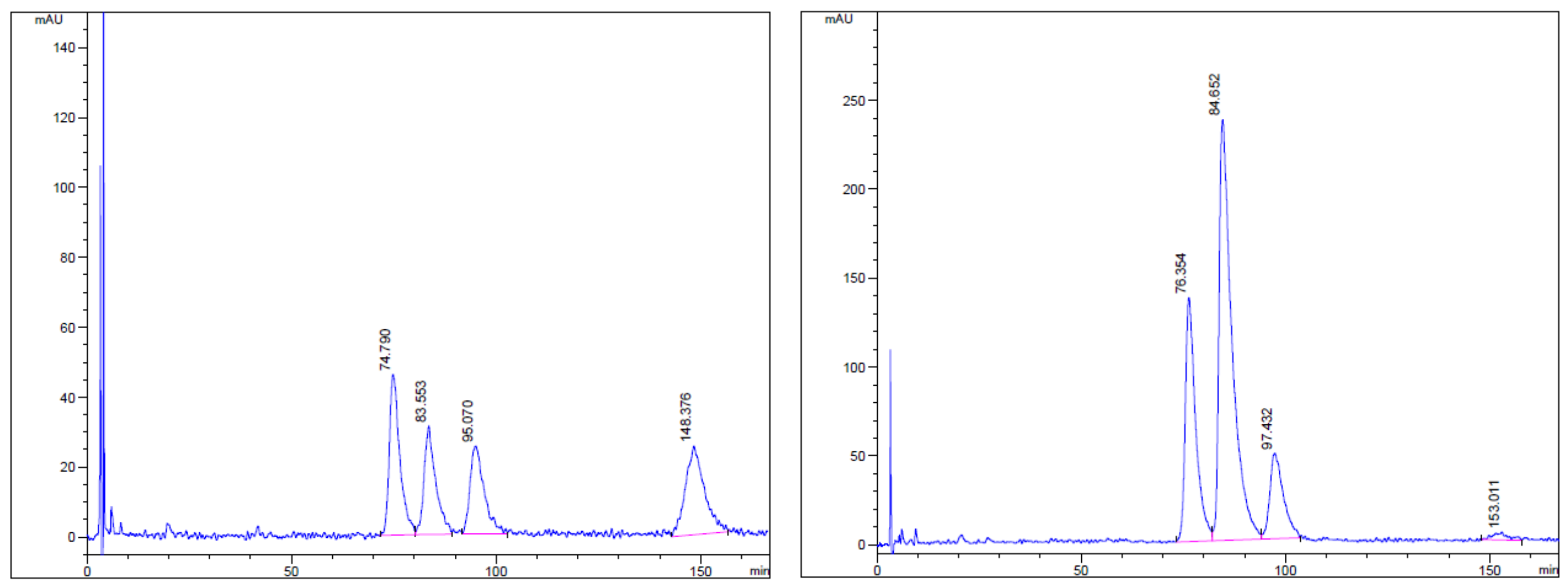

Signal 1: VWD1 A, Wavelength=210 nm

Signal 1: VWD1 A, Wavelength=210 nm

\begin{tabular}{|c|c|c|c|c|c|c|c|c|}
\hline I Pea & akl & RT & I Type & I & Width I & Area & Area of 1 & Name \\
\hline $1 \#$ & I & {$[\mathrm{min}]$} & I & I & [min] | & I & I & \\
\hline $1--$ & --1 & $\cdots$ & $1--$ & $-1-$ & -----1 & -------- & $------\mid$ & \\
\hline I & 11 & 74.79 & $0 \mid \mathrm{MF}$ & I & 2.9851 & 8239.5501 & 28.7561 & \\
\hline & 21 & 83.55 & $3 \mid \mathrm{MF}$ & I & 3.2981 & 6136.2701 & 21.415 I & \\
\hline & 31 & 95.07 & $0 \mid \mathrm{MM}$ & 1 & 4.0301 & 6074.6311 & 21.2001 & \\
\hline & 41 & 148.37 & $6 / \mathrm{MM}$ & I & 5.3781 & 8202.9661 & $28.628 \mid$ & \\
\hline
\end{tabular}

\begin{tabular}{|c|c|c|c|c|c|c|c|c|c|}
\hline \multicolumn{2}{|c|}{ |Peak| } & RT & I Type & 1 & Width | & Area & Area \& 1 & \multirow[t]{2}{*}{ Name } & I \\
\hline $1=$ & I & {$[\mathrm{min}]$} & 1 & 1 & [min] । & I & I & & 1 \\
\hline & --1 & --- & $-1--$ & -1 & -----1 & $--------\mid$ & -------1 & & \\
\hline 1 & 11 & 76.3 & $4 \mid \mathrm{MF}$ & I & 2.9651 & 24425.9821 & 27.3421 & & \\
\hline I & 21 & 84.6 & $2 \mid \mathrm{MF}$ & I & 3.6941 & 52532.0901 & 58.8031 & & \\
\hline । & 31 & 97.4 & $2 \mid F M$ & I & 3.8801 & 11214.0931 & $12.553 \mid$ & & \\
\hline & 41 & 153.0 & $1 \mid \mathrm{MM}$ & I & 4.3411 & 1162.9951 & 1.3021 & & \\
\hline
\end{tabular}


Figure S29. HPLC chromatograms of rac-3g and 3g
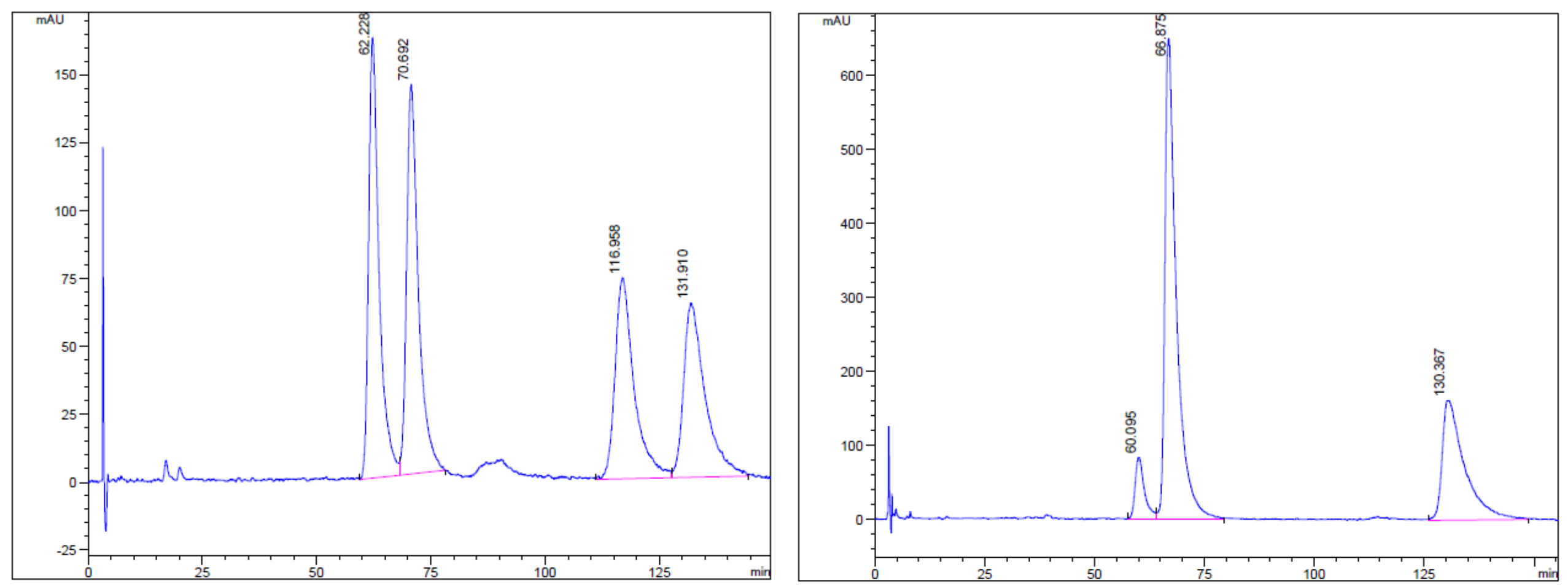

Signal 1: VWD1 A, Wavelength $=210 \mathrm{~nm}$

Signal 1: VWD1 $A$, Wavelength $=210 \mathrm{~nm}$

\begin{tabular}{|c|c|c|c|c|c|c|c|c|c|}
\hline \multicolumn{2}{|c|}{ |Peak| } & RT & I Type & I & Width I & Area & Area of 1 & Name & I \\
\hline $1 \neq$ & I & {$[\mathrm{min}]$} & 1 & I & [min] | & I & I & & 1 \\
\hline $1-$ & $--1-$ & ----- & $1--$ & -1 & ------1 & $---------\mid$ & --- & & \\
\hline 1 & 11 & 62.22 & $8 \mid \mathrm{MF}$ & I & 2.6681 & 26003.1501 & $27.517 \mid$ & & I \\
\hline 1 & 21 & $70.6 s$ & $2 \mid F M$ & I & 2.9981 & 25822.6451 & 27.3261 & & \\
\hline 1 & 31 & 116.95 & $8 \mid \mathrm{MF}$ & I & 4.8571 & 21617.3851 & 22.8761 & & \\
\hline I & 41 & 131.9 & $0 \mid \mathrm{FM}$ & I & 5.4601 & $21056.447 \mid$ & 22.2821 & & I \\
\hline
\end{tabular}

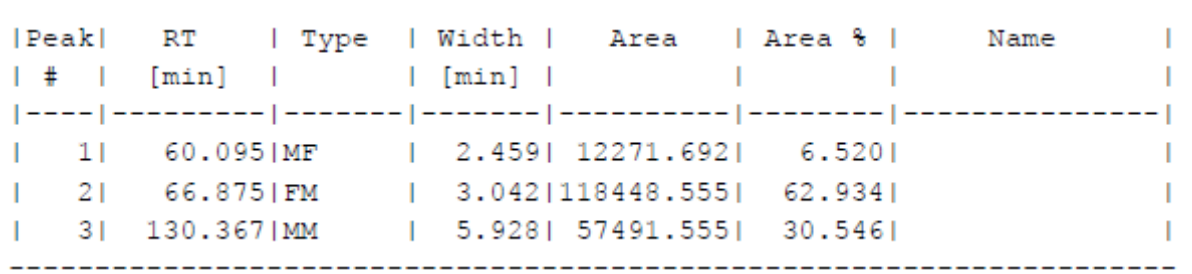


Figure S30. HPLC chromatograms of rac-3h and $\mathbf{3 h}$

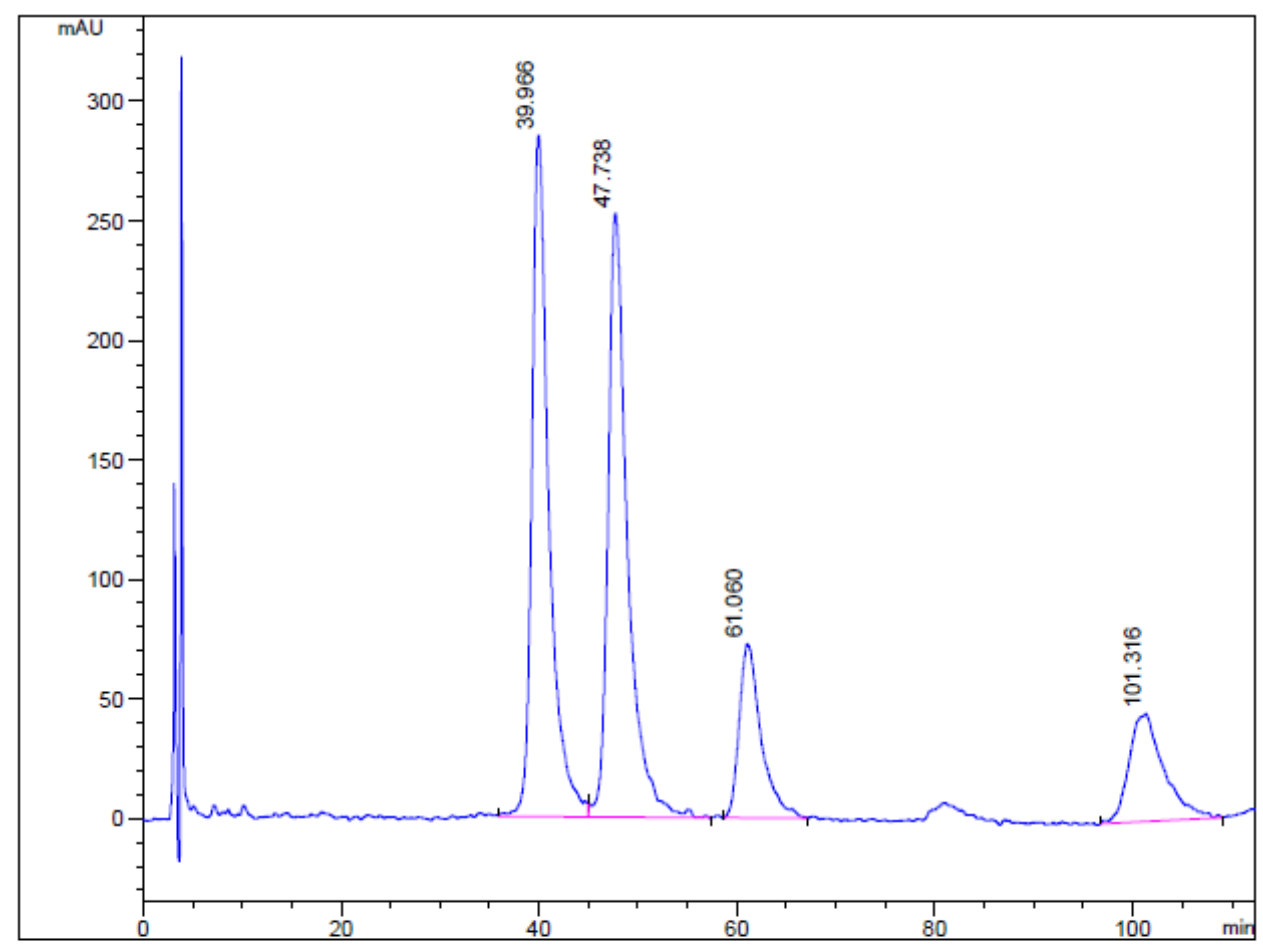

Signal 1: VWD1 $\mathbb{A}$, Wavelength=210 $\mathrm{nm}$

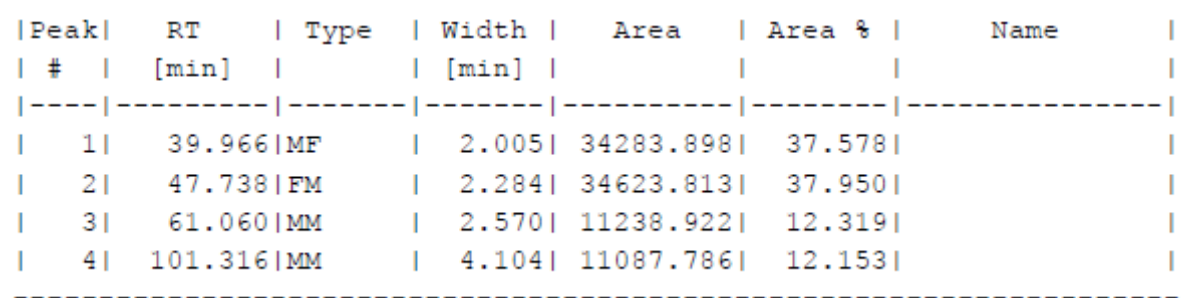

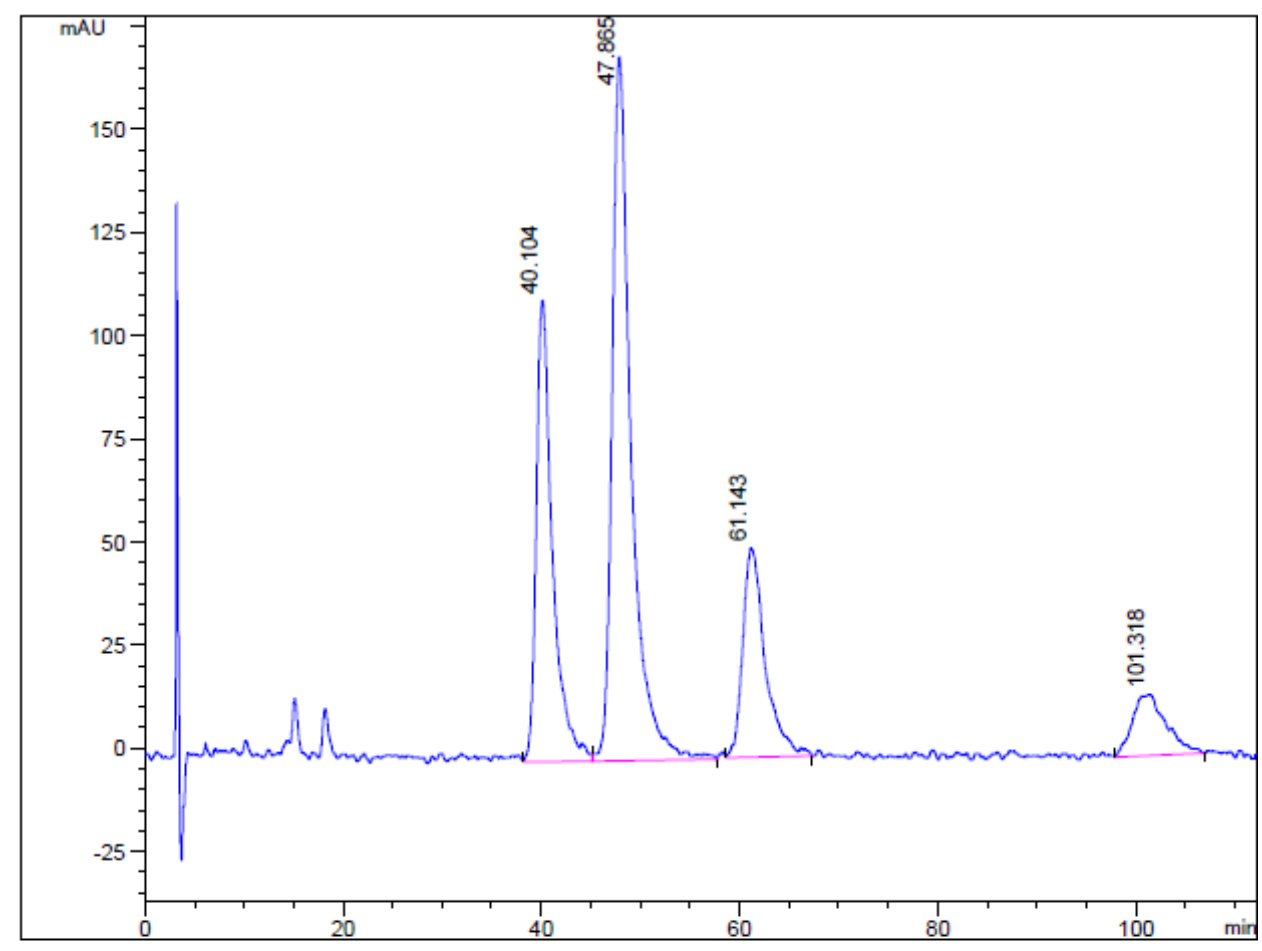

Signal 1: VWD1 A, Wavelength $=210 \mathrm{~nm}$

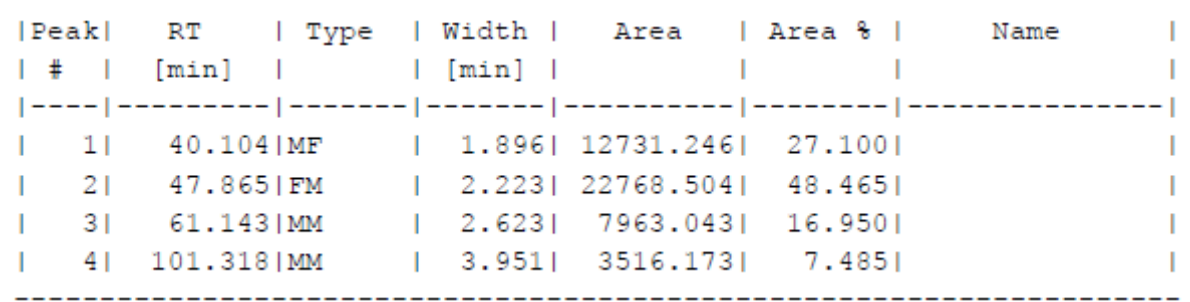


Figure S31. HPLC chromatograms of rac-3i and $\mathbf{3 i}$
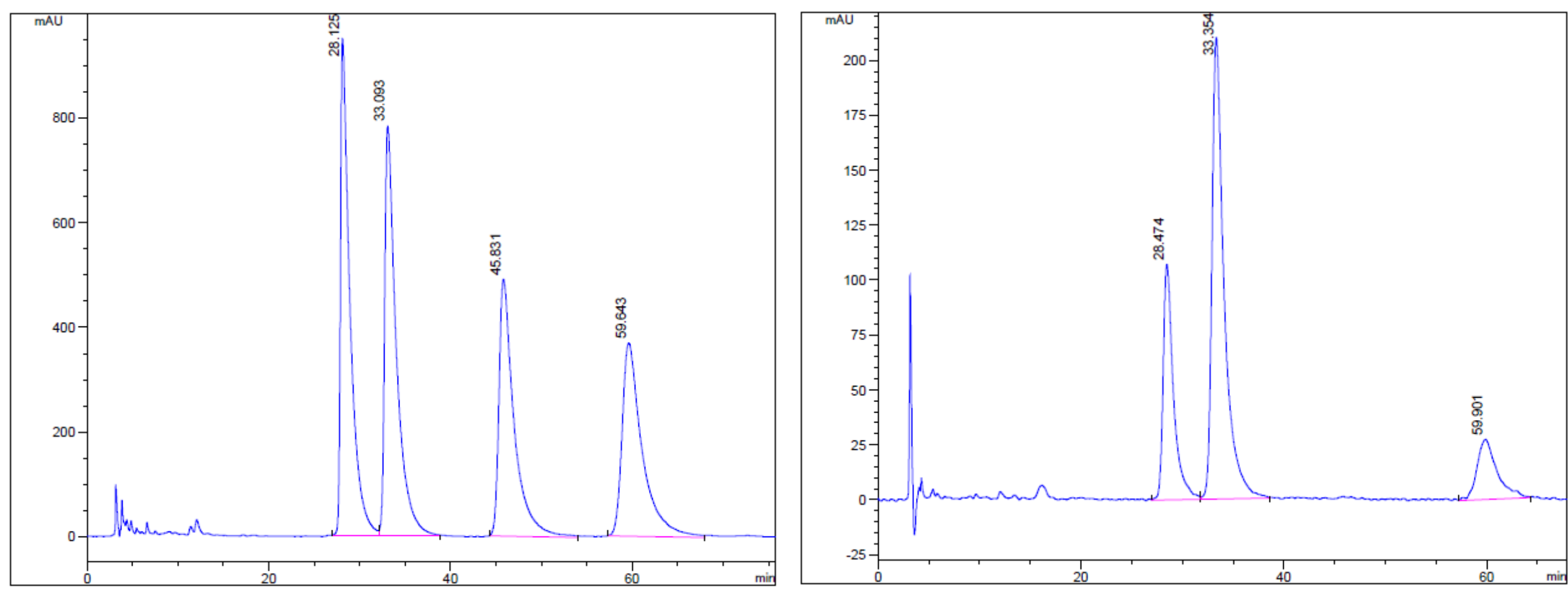

Signal 1: VWD1 A, Wavelength=210 nm

Signal 1: VWD1 A, Wavelength=210 nm

\begin{tabular}{|c|c|c|c|c|c|c|c|c|}
\hline & RT & I Type & 1 & Width I & Area & Area \& 1 & Name \\
\hline \multicolumn{2}{|c|}{$\begin{array}{l}\text { |Peak| } \\
|\#|\end{array}$} & [min] & 1 & I & [min] । & I & I & \\
\hline & -1 & --- & $1--$ & -1. & ----1 & ------ & ------1 & \\
\hline I & 11 & 28.1 & $5 \mid \mathrm{MF}$ & I & 1.2151 & 69244.9841 & 27.434 I & \\
\hline | & 21 & 33.0 & $3 \mid F M$ & I & 1.4831 & $69743.547 \mid$ & 27.6321 & \\
\hline | & 31 & 45.8 & 1 | MM & I & 1.9241 & $56749.254 \mid$ & 22.4831 & \\
\hline & 41 & 59.6 & $3 \mid \mathrm{MM}$ & I & 2.5551 & 56667.3201 & 22.4511 & \\
\hline
\end{tabular}


Figure S32. HPLC chromatograms of rac-3j and $\mathbf{3 j}$
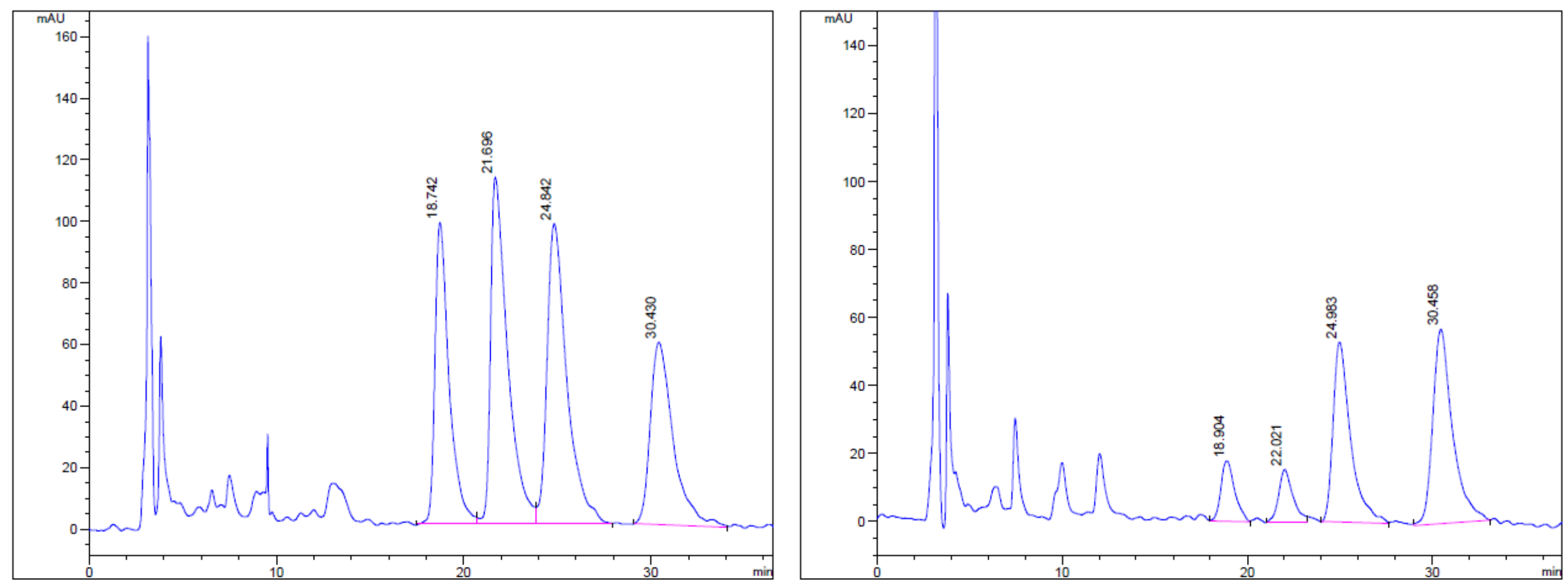

Signal 1: VWD1 A, Wavelength=210 nm

Signal 1: VWD1 A, Wavelength=210 nm

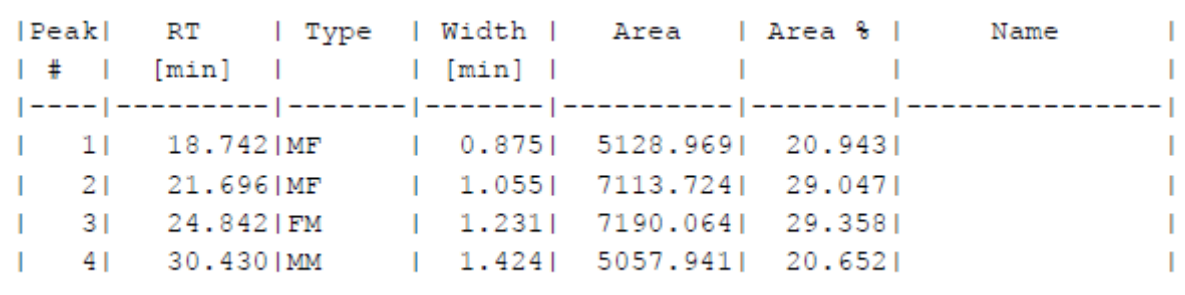

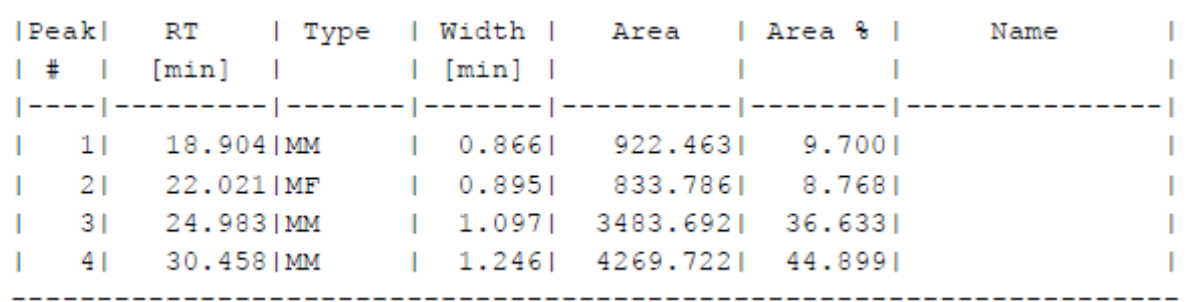


Figure S33. HPLC chromatograms of rac-3k and 3k

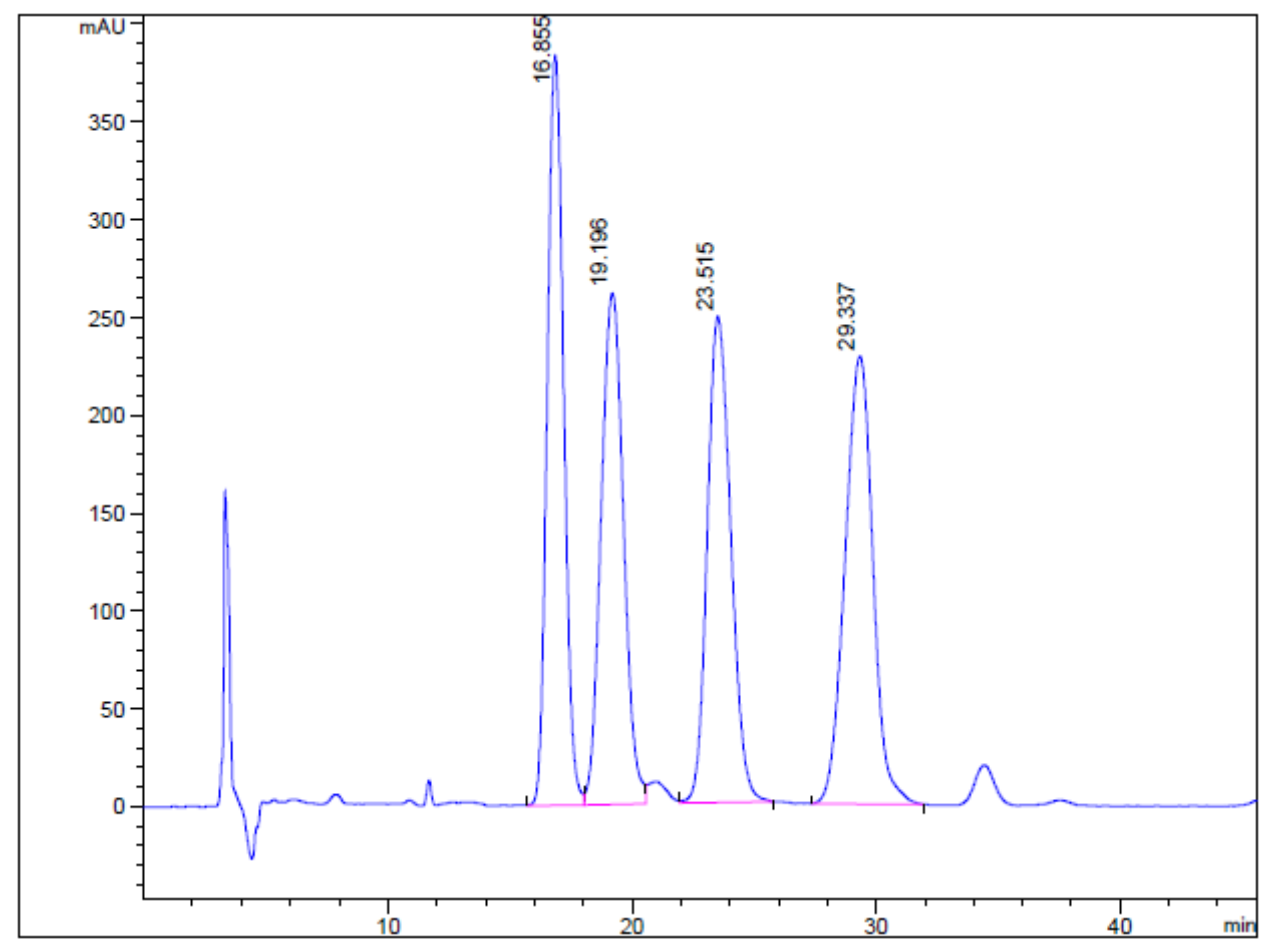

Signal 1: MWD1 C, Sig=210, 8 Ref $=360,100$

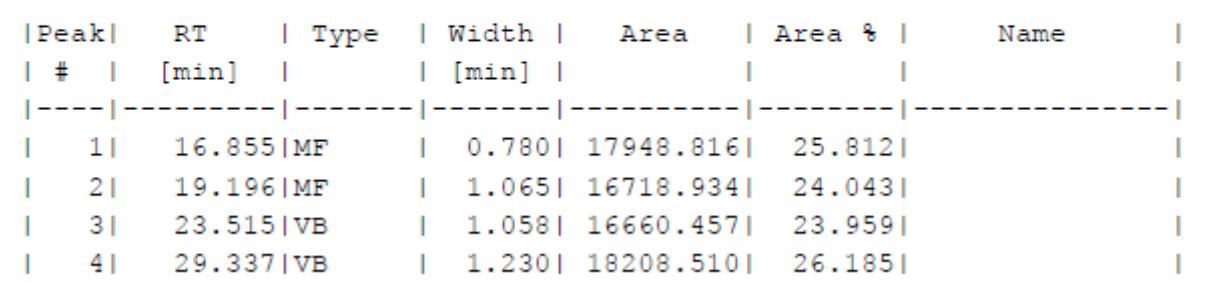

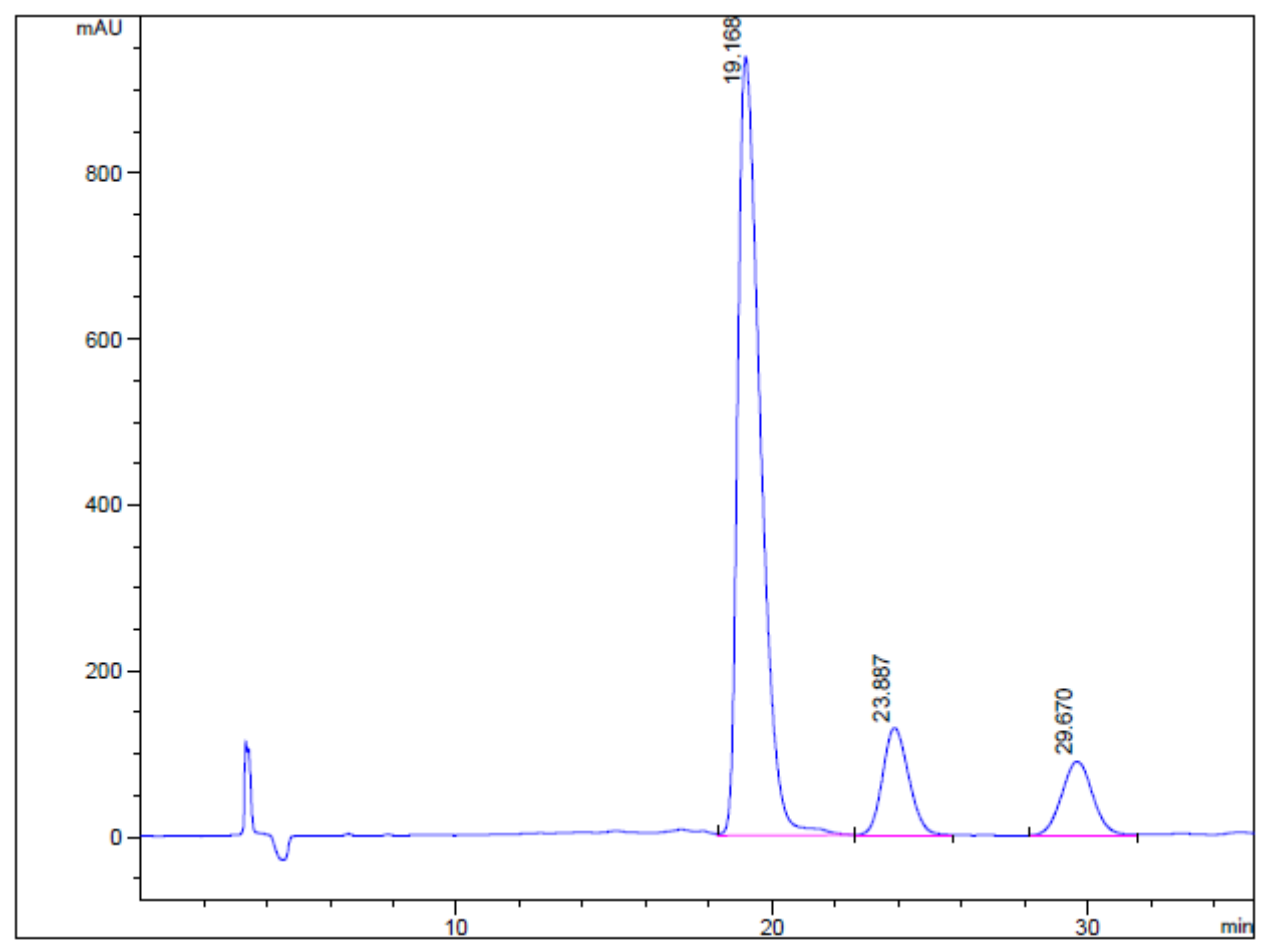

Signal 1: MWD1 C, $S i g=210,8$ Ref $=360,100$

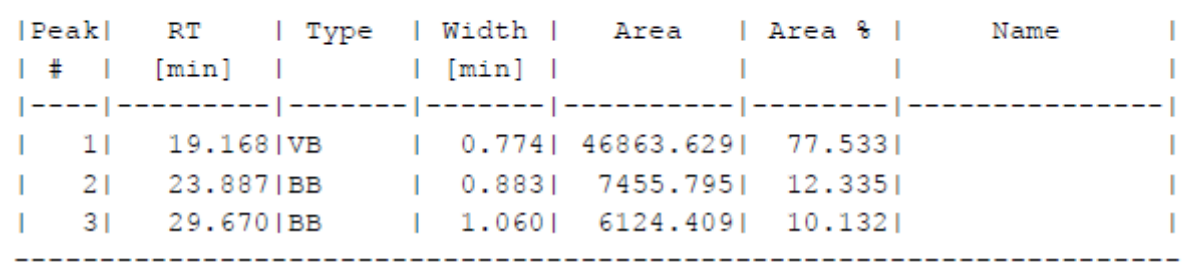


Figure S34. HPLC chromatogram of rac-4a

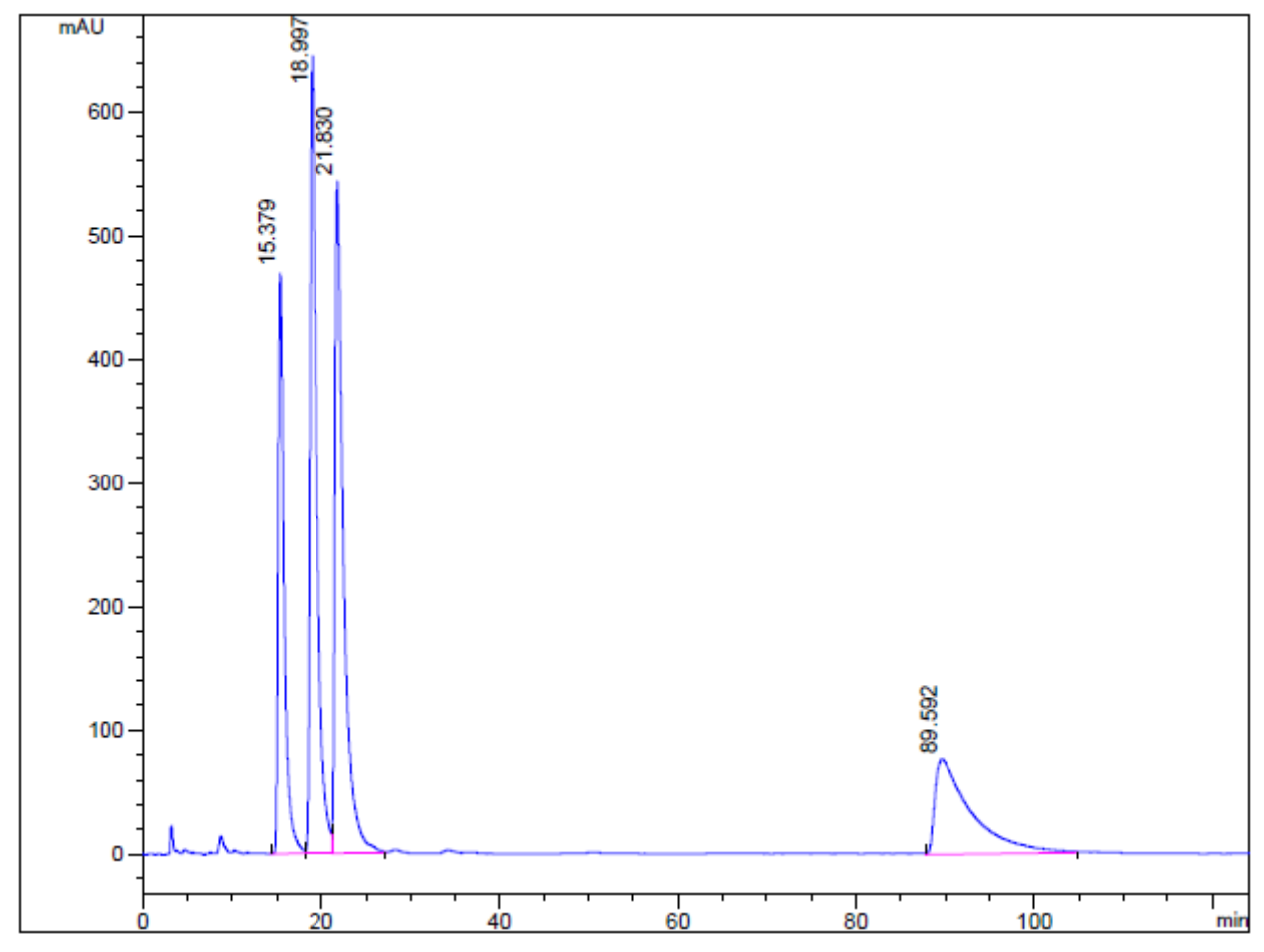

Signal 1: VWD1 $\mathrm{A}$, Wavelength $=210 \mathrm{~nm}$

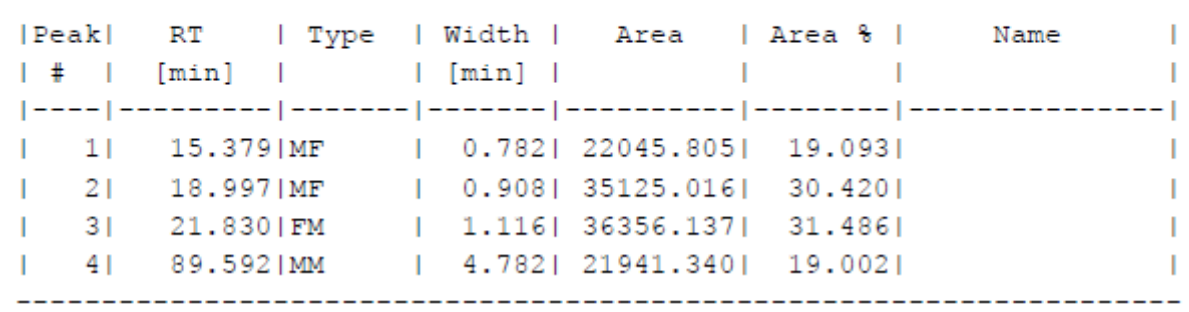


Figure S35. HPLC chromatograms of major diastereoisomer of $\mathbf{4 a}$ and minor diastereoisomer of $\mathbf{4 a}$
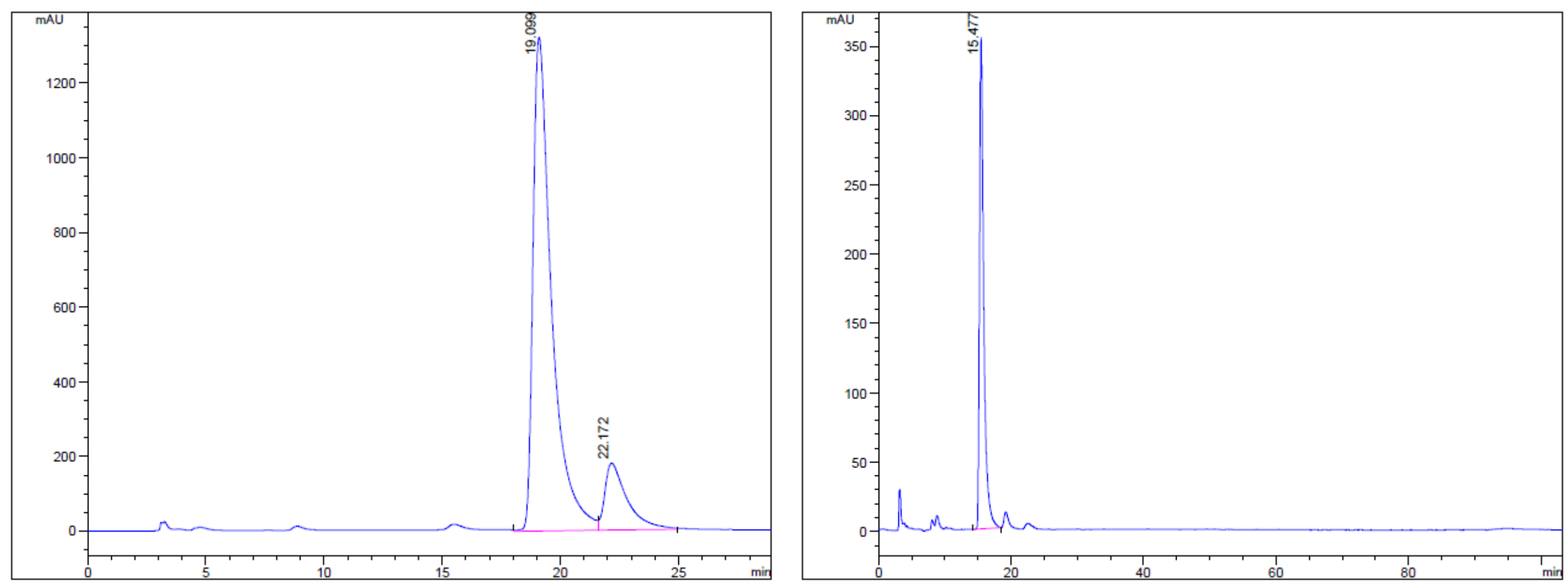

Signal 1: VWD1 A, Wavelength=210 nm

Signal 1: VWD1 A, Wavelength=210 nm

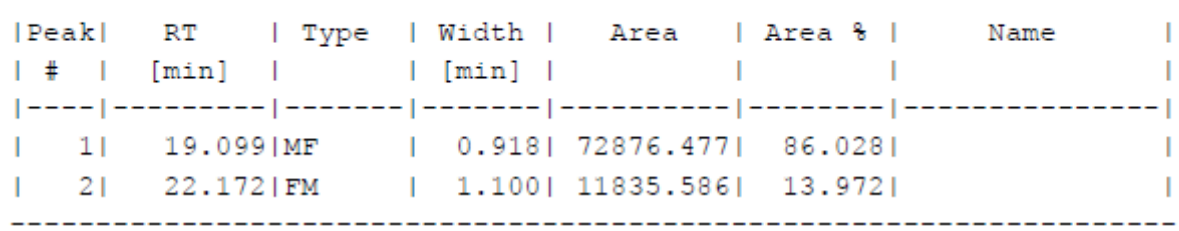

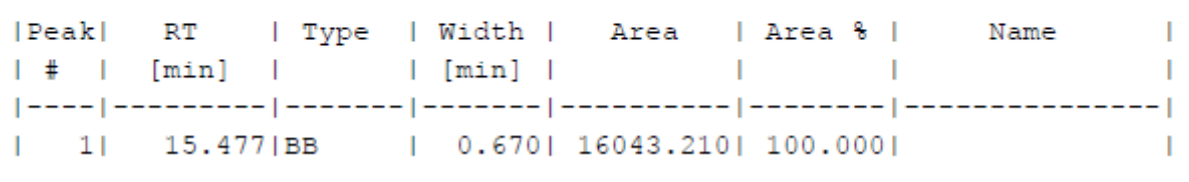

